\title{
Nadzór nad lecznictwem uzdrowiskowym ze szczególnym uwzględnieniem czynności kontrolno-nadzorczych nad zakładami lecznictwa uzdrowiskowego
}

\section{Wprowadzenie}

Przedmiotem niniejszego artykułu jest instytucja nadzoru nad lecznictwem uzdrowiskowym, w ramach którego właściwe organy dokonują kontroli i oceny lecznictwa uzdrowiskowego prowadzonego w zakładach lecznictwa uzdrowiskowego.

Podjęcie badań nad tym zagadnieniem wymaga w pierwszej kolejności omówienia swoistej siatki pojęciowej charakterystycznej dla problematyki uzdrowiskowej. W kontekście lecznictwa uzdrowiskowego i zakładów lecznictwa uzdrowiskowego w polskim porządku prawnym zasadnicze znaczenie mają dwie regulacje ustawowe: (1) Ustawa z dnia 28 lipca 2005 r. o lecznictwie uzdrowiskowym, uzdrowiskach i obszarach ochrony uzdrowiskowej oraz o gminach uzdrowiskowych ${ }^{1}$ oraz (2) Ustawa z dnia 15 kwietnia 2011 r. o działalności leczniczej². Ich analiza pozwala na dokonanie podstawowych ustaleń terminologicznych.

Zgodnie z art. 2 pkt 1 ustawy uzdrowiskowej lecznictwo uzdrowiskowe oznacza zorganizowaną działalność polegającą na udzielaniu świadczeń opieki zdrowotnej z zakresu leczenia uzdrowiskowego albo rehabilitacji uzdrowiskowej, prowadzoną w uzdrowisku przez zakłady lecznictwa

* Paulina Jachimowicz-Jankowska, dr, Uniwersytet im. Adama Mickiewicza w Poznaniu, e-mail: janpkows@amu.edu.pl, https://orcid.org/0000-0002-6061-1220.

${ }^{1}$ Tekst jedn. Dz.U. 2021, poz. 1301, dalej „ustawa uzdrowiskowa”.

${ }^{2}$ Tekst jedn. Dz.U. 2021, poz. 711, dalej „u.d.1.”. 
uzdrowiskowego albo poza uzdrowiskiem w szpitalach i sanatoriach znajdujących się w urządzonych podziemnych wyrobiskach górniczych, przy wykorzystaniu warunków naturalnych, takich jak: (a) właściwości naturalne surowców leczniczych, (b) właściwości lecznicze klimatu, w tym talasoterapia i subterraneoterapia, oraz właściwości lecznicze mikroklimatu - a także towarzyszących zabiegów z zakresu fizjoterapii. Trzeba tu od razu podkreślić, że w myśl art. 4 ust. 1 tego aktu lecznictwo uzdrowiskowe jest integralną częścią systemu ochrony zdrowia. To unormowanie wprost ujęte $\mathrm{w}$ przedmiotowej ustawie jest niezwykle ważne, gdyż koresponduje z postanowieniami art. 68 Konstytucji Rzeczypospolitej Polskiej z dnia 2 kwietnia 1997 r. $^{3}$ wyznaczającymi prawo do ochrony zdrowia, czyli prawo stanowiące jedno z podstawowych praw człowieka, przysługujące ze swej natury każdemu ${ }^{4}$. Co więcej, stosownie do art. 4 ust. 2 ustawy uzdrowiskowej w uzdrowiskach lecznictwo uzdrowiskowe jest prowadzone w zakładach lecznictwa uzdrowiskowego.

Sa tu zatem istotne dwie definicje. Po pierwsze - uzdrowisko to oznaczony wydzielony obszar, na terenie którego prowadzone jest lecznictwo uzdrowiskowe - w celu wykorzystania i ochrony znajdujących się na nim naturalnych surowców leczniczych - spełniający łącznie następujące warunki $\mathrm{i}^{5}$ : (1) posiada złoża naturalnych surowców leczniczych o potwierdzonych właściwościach leczniczych na zasadach określonych w ustawie; (2) posiada klimat o właściwościach leczniczych potwierdzonych na zasadach określonych w ustawie; (3) na jego obszarze znajdują się zakłady lecznictwa uzdrowiskowego i urządzenia lecznictwa uzdrowiskowego, przygotowane do prowadzenia lecznictwa uzdrowiskowego; (4) spełnia określone w przepisach o ochronie środowiska wymagania w stosunku do środowiska; (5) posiada infrastrukturę techniczną w zakresie gospodarki wodno-ściekowej, energetycznej, w zakresie transportu zbiorowego, a także prowadzi gospodarkę odpadami. Trzeba przy tym pamiętać, że z pojęciem uzdrowiska nieodzownie związana jest także inna instytucja, tj. gmina uzdrowiskowa, wedle art. 2 pkt 2 ustawy uzdrowiskowej oznaczająca gminę ${ }^{6}$ - będącą pod-

${ }^{3}$ Konstytucja Rzeczypospolitej Polskiej z dnia 2 IV 1997 r. (Dz.U. Nr 78, poz. 483 ze zm.), dalej "Konstytucja RP”.

${ }^{4}$ Szerzej zob. K. Ryś, Konstytucyjne prawo do ochrony zdrowia i prawo do szczególnej opieki zdrowotnej, "Zeszyty Naukowe Prawa Konstytucyjnego” 2017, nr 10, s. 113-126.

${ }^{5}$ Warunki te są wskazane w art. 34 ust. 1 ustawy uzdrowiskowej.

${ }^{6}$ Status prawny gminy reguluje Ustawa z dnia 8 III 1990 r. o samorządzie gminnym (tekst jedn. Dz.U. 2021, poz. 1372, dalej "u.s.g."). 
stawową jednostką samorządu terytorialnego (j.s.t.) - której obszarowi lub jego części został nadany status uzdrowiska w trybie określonym w ustawie.

Po drugie - dopełnieniem terminologii uzdrowiskowej jest definicja zakładu lecznictwa uzdrowiskowego, zgodnie bowiem z art. 2 pkt 10 ustawy uzdrowiskowej zakład lecznictwa uzdrowiskowego oznacza zakład leczniczy, w którym podmiot leczniczy wykonuje działalność leczniczą $w$ rodzaju ambulatoryjne lub stacjonarne i całodobowe świadczenia zdrowotne w rozumieniu przepisów o działalności leczniczej, działający na obszarze uzdrowiska, utworzony w celu udzielania świadczeń zdrowotnych z zakresu lecznictwa uzdrowiskowego albo rehabilitacji uzdrowiskowej, w ramach kierunków leczniczych i przeciwwskazań ustalonych dla danego uzdrowiska, w szczególności wykorzystujących warunki naturalne uzdrowiska przy udzielaniu świadczeń zdrowotnych.

Interesujące jest to, że przywołana terminologia jest uregulowana w u.d.l. Ramy opracowania nie pozwalają na szeroką analizę i tym bardziej ocenę zakresu przedmiotowego tej ustawy określonego w art. 1 u.d.l., niemniej jednak trzeba zauważyć, iż intencją ustawodawcy wprowadzającego tę regulację do obrotu prawnego było wskazanie, że „istotą ustawy jest prowadzenie przez podmioty lecznicze profesjonalnej działalności leczniczej"7. W kontekście zakładów lecznictwa uzdrowiskowego u.d.l. ma duże znaczenie, art. 15 ustawy uzdrowiskowej stanowi bowiem, że w sprawach nieuregulowanych w ustawie do zakładów lecznictwa uzdrowiskowego mają zastosowanie przepisy Ustawy z dnia 15 kwietnia 2011 r. o działalności leczniczej. Dlatego warto tu podać jeszcze trzy definicje legalne określone w u.d.l., a odnoszące się do przedmiotowych zakładów, takie jak: świadczenie zdrowotne, zakład leczniczy i działalność lecznicza. Uwzględniając w tym zakresie regulacje u.d.l.: świadczenie zdrowotne $^{8}$ oznacza działania służące zachowaniu, ratowaniu, przywracaniu lub poprawie zdrowia oraz inne działania medyczne wynikające z procesu leczenia lub przepisów odrębnych regulujących zasady ich wykonywania (art. 2 ust. 1 pkt 10); zakład leczniczy to zespół składników majątkowych, za pomocą którego podmiot leczniczy wykonuje określony

${ }^{7}$ Zob. M. Dercz, Komentarz do art. 1, w: M. Dercz, T. Rek, Ustawa o działalności leczniczej. Komentarz, Warszawa 2019, s. 31-32.

${ }^{8}$ Zob. też definicję tego świadczenia według art. 5 pkt 40 Ustawy z dnia 27 VIII 2004 r. o świadczeniach opieki zdrowotnej finansowanych ze środków publicznych (tekst jedn. Dz.U. 2021, poz. 1285, dalej „u.ś.o.z."). 
rodzaj działalności leczniczej (art. 2 ust. 1 pkt 14); działalność lecznicza polega na udzielaniu świadczeń zdrowotnych, przy czym świadczenia te mogą być udzielane za pośrednictwem systemów teleinformatycznych lub systemów łączności. Ponadto działalność lecznicza może polegać na: promocji zdrowia lub realizacji zadań dydaktycznych i badawczych $\mathrm{w}$ powiązaniu $\mathrm{z}$ udzielaniem świadczeń zdrowotnych i promocją zdrowia, w tym $z$ wdrażaniem nowych technologii medycznych oraz metod leczenia (art. 3 ust. $1 \mathrm{w}$ zw. $\mathrm{z}$ art. 3 ust. 2).

Zagadnienie nadzoru nad lecznictwem uzdrowiskowym zasadni$\mathrm{Czo}^{9}$ rzadko stanowi zainteresowanie przedstawicieli doktryny, dlatego wydaje się celowe poświęcić tej problematyce nieco więcej uwagi. Ze względu na to, że analizowany nadzór dotyczy działalności zakładów lecznictwa uzdrowiskowego, które są podmiotami leczniczymi, dla uporządkowania dalszych rozważań omówiono najpierw unormowania wynikające z ustawy uzdrowiskowej, a następnie regulacje u.d.l., stanowiące dopełnienie ustawy uzdrowiskowej.

Wypada w tym miejscu zauważyć, że o ile instytucja nadzoru w administracji zdecentralizowanej ${ }^{10}-\mathrm{w}$ ramach której jedną z jej postaci jest samorząd terytorialny ${ }^{11}$ - ma specyficzny charakter, o tyle jednostki nadzorowane $\mathrm{z}$ założenia są podmiotami samodzielnymi, wyposażonymi w osobowość prawna, a ich samodzielność ex lege podlega ochronie

${ }^{9}$ Co nie oznacza, że wcale, zob. np. P. Kledzik, Nadzór nad lecznictwem uzdrowiskowym, w: Szczególny status gminy uzdrowiskowej - z perspektywy 10 lat obowiązywania ustawy o lecznictwie uzdrowiskowym, uzdrowiskach i obszarach ochrony uzdrowiskowej oraz o gminach uzdrowiskowych, pod red. E. Koniuszewskiej, Szczecin 2016, s. 89-112; T. Zimna, Nadzór i kontrola w zakładach lecznictwa uzdrowiskowego, ABC nr 72409, LEX \el., https://sip.lex. $\mathrm{pl} /$ komentarze-i-publikacje/komentarze-praktyczne/nadzor-i-kontrola-w-zakladach-lecznictwa-469834457 (dostęp: 10 IX 2021). Pewne elementy nadzoru nad lecznictwem uzdrowiskowym omawia K. Sikora, Szczególny status gmin uzdrowiskowych w Polsce, „Studia Iuridica Lublinensia" 2014, nr 23, s. 107-124.

${ }^{10} \mathrm{~W}$ ramach tego procesu niezbędne jest wzmacnianie nadzoru państwa nad podmiotami, co jest bezpośrednio związane ze stosowaniem kontroli jako instytucji wspomagającej. Szerzej zob. Z. Janku, Kontrolowanie samorządu terytorialnego, w: Księga jubileuszowa prof. dr. hab. S. Jędrzejowskiego, pod red. W. Szwajdlera, H. Nowickiego, Toruń 2009, s. 203-212; Z. Leoński, Nadzór nad działalnościa gminy, Warszawa 1992, s. 4.

11 Tak np. E. Ura, Prawo administracyjne, Warszawa 2010, s. 193. Według ujęcia doktryny samorząd terytorialny "to wyodrębniony w strukturze państwa, powstały z mocy prawa, związek lokalnego społeczeństwa, powołany do samodzielnego wykonywania administracji publicznej, wyposażony w materialne środki umożliwiające realizację nałożonych nań zadań" bądź „forma organizacji społeczności lokalnych powołana do kierowania i zarządzania sprawami publicznymi w interesie mieszkańców" (E. Ochendowski, Prawo administracyjne. Część ogólna, Torun 1999, s. 299). 
sądowej. Nie występuje tu ani osobowa, ani służbowa zależność między podmiotami nadzorującymi i nadzorowanymi ${ }^{12}$ - tym samym organy wyższego stopnia nie są hierarchicznie podporządkowane organom wyższego stopnia ${ }^{13}$. Nadzór państwa nad samorządem terytorialnym (gminnym) jest wobec tego uzasadniony, a nawet konieczny ${ }^{14}$. Gmina uzdrowiskowa ${ }^{15}$ terytorialnie przynależy zatem do państwa, a status gminy podlega regulacjom państwowego porządku prawnego.

Prowadzone wywody pozwalają ustalić, że działalność, jaką jest lecznictwo uzdrowiskowe, stanowi z kolei przejaw systemu administracji niezdecentralizowanej. Nadzór oznacza tu bowiem władcze wpływanie przez organ hierarchicznie nadrzędny na działalność organu podporządkowanego. Jak trafnie zauważa A. Wiktorowska ${ }^{16}$, nadzór $\mathrm{w}$ administracji zdecentralizowanej z samego założenia nie jest i nie może być tak intensywny jak w administracji scentralizowanej, w przypadku której graniczy niemalże z kierownictwem.

Celem prezentowanego opracowania jest analiza i ocena nadzoru nad lecznictwem uzdrowiskowym, ze szczególnym uwzględnieniem czynności kontrolno-nadzorczych sprawowanych nad zakładem lecznictwa uzdrowiskowego. $\mathrm{W}$ ramach tego zagadnienia wskazano i przytoczono niektóre definicje pojęcia kontroli i nadzoru w ujęciu doktryny, omówiono sferę przedmiotową nadzoru nad lecznictwem uzdrowiskowym, zbadano właściwe organy oraz środki kontroli i nadzoru nad zakładami lecznictwa uzdrowiskowego w kontekście zarówno ustawy uzdrowiskowej, jak i ustawy o działalności leczniczej, a także

12 Por. Z. Leoński, Zarys prawa administracyjnego. Działalność administracji, Warszawa 2001, s. 42.

${ }^{13}$ Szerzej: E. Ura, Prawo... (2010), s. 96-97; P. Winczorek, Komentarz do Konstytucji polskiej z dnia 2 kwietnia 1997 r., Warszawa 2000, s. 13. Z regulacji prawnych zob. postanowienia Konstytucji RP wprowadzające dwie podstawowe zasady ustrojowe, tj. rozdział I, zwł. art. 15 ust. 1 i art. 16 ust. 2, a także postanowienia odnoszące się wprost do funkcjonowania samorządu terytorialnego w Polsce, w tym gminy uzdrowiskowej, tj. art. 163 i art. 164 ust. 3 Konstytucji RP.

${ }^{14} \mathrm{~W}$ opracowaniu A. Wiktorowska, Samorzad terytorialny, w: Prawo administracyjne, pod red. M. Wierzbowskiego, Warszawa 2017, s. 236, autorka analizuje nadzór nad samorządem terytorialnym. Na temat definicji pojęcia nadzoru szerzej zob. np. B. Dolnicki, Samorząd terytorialny, Kraków 2001, s. 25-26.

${ }^{15}$ Zob. np. J. Korczak, Gmina uzdrowiskowa w prawodawstwie polskim, "Opolskie Studia Administracyjno-Prawne" 2018, t. 16, nr 1(1), s. 99-118.

${ }^{16}$ A. Wiktorowska, Prawne determinanty samodzielności gminy. Zagadnienia administracyjnoprawne, Warszawa 2002, s. 192. 
zaprezentowano odrębne tryby kontroli prowadzonej na specyficznym obszarze gminy, której nadano status gminy uzdrowiskowej.

\section{Kontrola i nadzór nad zakładami lecznictwa uzdrowiskowego - ustalenia terminologiczne i zwięzły przegląd pojęć definicyjnych o kontroli i nadzorze}

Problematykę kontroli i nadzoru nad zakładami lecznictwa uzdrowiskowego reguluje przede wszystkim ustawa uzdrowiskowa oraz u.d.l. Lecznictwo uzdrowiskowe - będące zorganizowaną działalnością, polegającą na udzielaniu świadczeń opieki zdrowotnej z zakresu leczenia uzdrowiskowego, prowadzoną w uzdrowisku przez zakłady lecznictwa uzdrowiskowego - to przejaw systemu administracji niezdecentralizowanej. Nadzór oznacza władcze wpływanie przez organ hierarchicznie nadrzędny na działalność organu podporządkowanego. W ramach tego procesu niezbędne jest wzmacnianie nadzoru państwa nad podmiotami, co - jak już wiadomo - jest bezpośrednio związane ze stosowaniem kontroli jako instytucji wspomagającej ${ }^{17}$.

Analizy polegające na rozpoznaniu tego typu fachowego ${ }^{18}$ nadzoru, jakim jest nadzór uzdrowiskowy, cechują odrębne unormowania i stopień skomplikowania. Chodzi tu o poszczególne zagadnienia pozwalające na odtworzenie istoty nadzoru, czyli: organy nadzorujące, przedmiot i podmioty nadzorowane, kryteria sprawowanego nadzoru oraz prawne środki nadzoru. Bez wątpienia o specyfice nadzoru nad lecznictwem uzdrowiskowym przesądza pozycja prawna naczelnego lekarza uzdrowiska. Leczenie to jest prowadzone w zakładach lecznictwa uzdrowiskowego w uzdrowisku, które determinuje szczególne tryby kontroli prowadzonej na tym obszarze.

Przegląd poglądów doktryny na temat kontroli i nadzoru pozwala na stwierdzenie, że te dwa określenia mają na celu zapewnienie prawidłowej działalności administracji publicznej. Pojęcia te są w polskiej doktrynie zdefiniowane od dawna w różny sposób ${ }^{19}$. Jak podnosi E. Ura,

${ }^{17}$ Szerzej zob. Z. Janku, Kontrolowanie samorzadu..., s. 203-212.

${ }_{18}$ Por. np. J. Zimmermann, Prawo administracyjne, Warszawa 2014, s. 157.

${ }^{19} \mathrm{~W}$ układzie chronologicznym różne definicje kontroli przytaczają np.: M. Jaroszyński, M. Zimmermann, W. Brzeziński, Polskie prawo administracyjne. Część ogólna, Warszawa 1956, s. 440; J. Starościak, Elementy nauki administracji, Warszawa 1964, s. 187; W. Dawidowicz, Zagadnienia ustroju administracji państwowej w Polsce, Warszawa 1970, s. 34; J. Starościak, Zarys nauki administracji, Warszawa 1971, s. 352; S. Jędrzejewski, 
„[t]erminy te nie są synonimami, mimo że działalność kontrolna i działalność nadzorcza polegają na sprawdzaniu prawidłowości działania organu administracji" ${ }^{\prime 20}$. W najnowszym ujęciu literaturowym kontrola oznacza badanie stanu istniejącego, rzeczywistego, i porównywanie go ze stanem postulowanym, a także ustalanie zakresu i przyczyn dostrzeżonych rozbieżności ${ }^{21}$. Co więcej, , [z] prawnego punktu widzenia kontrola jest czynnością faktyczną, a jej istotą jest porównanie stanu zastanego w toku czynności ze stanem pożądanym" ${ }^{\prime 22}$. Charakterystyczną cechą kontroli jest występowanie przeciw niechcianym zjawiskom, sygnalizowanie jednostkom o dokonanych spostrzeżeniach, jednakże bez możliwości wpływania na dalszą ich działalnośćc ${ }^{23}$. Organ wyposażony w prawo kontroli ma zazwyczaj prawo wydawania zaleceń jednostkom kontrolowanym, a w przypadkach wyjątkowych, w celu uniknięcia strat - prawo wydawania poleceń (zwanych często zarządzeniami doraźnymi) natychmiastowego usunięcia nieprawidłowości. Zasadniczo jednak organ kontrolujący przedstawia tylko wyniki wraz z wypływającymi z tego wnioskami ${ }^{24}$.

Działania kontrolne mogą występować samoistnie na zasadzie funkcjonowania samodzielnych kompetencji, których celem stosowania jest wyłącznie sprawdzanie i ocenianie, bez ingerowania w kontrolowaną działalność. Mogą być też elementem składowym innych instytucji: nadzoru czy kierownictwa. Według J. Jagielskiego treść funkcji kontroli obejmuje: obserwowanie i rozpoznawanie danej działalności lub stanu, czyli ustalanie ich rzeczywistego obrazu w określonym czasie, ocenę tej działalności lub stanu przez konfrontację rzeczywistego, faktycznego ich obrazu z odnoszącymi się do nich jako całości, jak również do poszczególnych fragmentów, założeniami wyjściowymi, prowadzącą do stwierdzenia, że są one prawidłowe lub nieprawidłowe, diagnozę co do przyczyn ewentualnych nieprawidłowości, mającą możliwie szeroki zasięg, w tym uwzględniającą aspekty zarówno przedmiotowe, jak i personalne przyczyn nieprawidłowości, oraz sformułowanie wniosków odnośnie do przeciwdziałania

H. Nowicki, Kontrola administracji publicznej, Toruń 1995, s. 7; J. Sługocki, Prawo administracyjne, Kraków 2003, s. 459.

${ }^{20}$ E. Ura, Prawo administracyjne, Warszawa 2012, s. 56.

${ }^{21}$ J. Zimmermann, Prawo administracyjne, Warszawa 2012, s. 150.

${ }^{22}$ M. Dulińska, Komentarz do działu VI - art.118-122, w: Ustawa o działalności leczniczej. Komentarz, pod red. F. Grzegorczyka, Warszawa 2013, s. 374.

${ }^{23}$ E. Ochendowski, Prawo administracyjne. Czesść ogólna, Toruń 2013, s. 433-434.

${ }^{24} \mathrm{M}$. Wierzbowski, A. Wiktorowska, Podstawowe pojęcia teoretyczne w nauce prawa administracyjnego, w: Prawo administracyjne, pod red. M. Wierzbowskiego, s. 81. 
powstawaniu nieprawidłowości w przyszłości ${ }^{25}$. Z kolei J. Boć podnosi, że kontrola ma charakter władczy tylko w tym znaczeniu, że podmiot kontrolowany nie może się od kontroli uchylić, a zastosowanie środków władczych w celu usunięcia stwierdzonych nieprawidłowości nie należy do organu kontrolującego. Funkcję tę spełnić może organ sprawujący nadzór. Jeśli kontrola sprawowana jest przez organ zwierzchni organizacyjnie nad kontrolowanym, a zatem także odpowiedzialny za jego działania, i jeśli temu organowi zwierzchniemu służą środki oddziaływania władczego wobec podrzędnego w strukturze podmiotu kontrolowanego, to kontrola przybiera kwalifikowaną postać nadzoru ${ }^{26}$. Nadzór jest więc pojęciem szerszym, gdyż oprócz kontroli oznacza również możliwość wiążącego wpływania na działalność organu nadzorowanego ${ }^{27}$.

Nadzór nie ogranicza się zatem wyłącznie do obserwacji i ustalania stanu faktycznego, lecz łączy się z możliwością stosowania środków nadzoru, czyli z prawem do wydawania poleceń co do zmiany kierunku działania. Organ dokonujący nadzoru, by mógł władczo oddziaływać na jednostki nadzorowane, musi mieć takie uprawnienia przyznane prawem. Uprawnienia nadzorcze oznaczaja prawo do kontroli wraz z możliwością wiążącego wpływania na organy czy instytucje nadzorowane. Zdaniem E. Ury „[n]adzór zawsze obejmuje kontrolę" ${ }^{\prime 28}$. Z pojęciem nadzoru, jak zauważa Z. Leoński, można się spotkać w literaturze i w obowiązującym prawie w dwojakim znaczeniu. Po pierwsze - ustawodawca $\mathrm{w}$ administracyjnym prawie materialnym używa określenia "nadzór" z reguły dla oznaczenia funkcji typu policyjnego ${ }^{29}$, mówiąc o nadzorze uzdrowiskowym. Dotyczy to administracji publicznej skierowanej do obywateli będących poza układem organów administracji. Po wtóre - ustawodawca oraz literatura używają określenia "nadzór" dla oznaczenia układu zależności między organami sprawującymi funkcje administracji publicznej ${ }^{30}$. Rozpatrując problematykę związaną z nadzorem, można przytoczyć kolejne stwierdzenie Z. Leońskiego, według

${ }^{25}$ J. Jagielski, Kontrola administracji publicznej, Warszawa 2007, s. 9.

${ }^{26}$ Prawo administracyjne, pod red. J. Bocia, Wrocław 2005, s. 394.

${ }^{27}$ Zob. np. J. Szreniawski, Wstęp do nauki administracji, Lublin 2004, s. 59. Na temat pojęcia nadzoru zob. np. B. Dolnicki, Nadzór nad samorządem terytorialnym, Katowice 1993; M. Szewczyk, Nadzórw materialnym prawie administracyjnym, Poznań 1996; A. Wiktorowska, Prawne determinanty..., s. 191-227; P. Chmielnicki, Akty nadzoru nad działalnościa samorzadu terytorialnego w Polsce, Warszawa 2006.

${ }^{28}$ E. Ura, Prawo... (2010), s. 70, i wskazana tam literatura.

${ }^{29}$ Z. Leoński, Samorzad terytorialny w RP, Warszawa 2002, s. 174.

${ }^{30}$ Ibidem. 
którego „intensywność nadzoru przesądza jednocześnie o istnieniu, ograniczeniu i granicach samodzielności podmiotów sprawujących funkcje administracji publicznej"31.

Nadzór można określić jako prawo do sprawdzania działalności podmiotu nadzorowanego, połączone z prawem do władczego ingerowania $\mathrm{w}$ tę działalność, $\mathrm{w}$ ściśle określonych przypadkach ${ }^{32}$. Natomiast J. Zimmermann stwierdza, że istotą nadzoru jest "wyciąganie konsekwencji z zachowania organu podporządkowanego". Te konsekwencje "organ nadzorczy wyprowadza, stosując środki nadzoru, którymi są możliwości władczego i jednostronnego oddziaływania na czynność organu nadzorowanego"33. W niektórych przypadkach termin ten bywa używany do oznaczenia kierownictwa lub kontroli, co wiąże się z tym, że nadzorowanie jest jednym z elementów funkcji kierowania. Podstawową cechą kierownictwa jest określony zakres władztwa, które wiąże się z władzą w szerszym pojęciu i daje możliwość np. kierowania zachowaniem podwładnych niezależnie od ich woli. Organ kierujący może używać wszelkich środków w celu oddziaływania na postępowanie organów kierowanych, z wyjątkiem tych, których użycia zakazuje prawo. Będą to również środki nadzoru ${ }^{34}$.

Instytucja nadzoru $\mathrm{w}$ prawie publicznym występuje $\mathrm{w}$ prawie materialnym w obrębie różnych zespołów kompetencji władczych, z których organy administracji korzystają $w$ relacjach zewnętrznych ${ }^{35}$. Na gruncie procedur administracyjnych chodzi o weryfikację rozstrzygnięć wydawanych przez organy administracji i administrujące $w$ toku instancji ${ }^{36}$.

${ }^{31}$ Z. Leoński, Samorząd terytorialny..., s. 175.

${ }^{32}$ M. Szewczyk, Nadzór..., s. 29.

${ }^{33}$ J. Zimmermann, Prawo administracyjne, Kraków 2006, s. 139.

${ }^{34}$ Zob. np. E. Knosala, Zarys nauki administracji, Kraków 2005, s. 253 i n.; M. Miemiec, Prewencja $i$ weryfikacja w ramach nadzoru i kierownictwa w ujęciu tradycyjnym, w: Nadzór administracyjny. Od prewencji do weryfikacji, pod red. C. Kocińskiego, Wrocław 2006, s. 47; E. Ura, Prawo... (2010), s. 73; Z. Kmieciak, Odwołania w postępowaniu administracyjnym, Warszawa 2011, s. 51, i wskazana tam literatura.

${ }^{35}$ Czynności w sferze zewnętrznej to te, które są dokonywane pomiędzy podmiotem administracji a podmiotem niepozostającym z nim w jakiejkolwiek zależności służbowej lub osobowej. Zob. np. Z. Leoński, Zarys prawa administracyjnego. Działalność..., s. 42; E. Ochendowski, Prawo administracyjne... (1999), s. 150-160; (2013), s. 185-194.

${ }^{36}$ Niektóre środki zaskarżania rozstrzygnięć administracyjnych zakwalifikowano w doktrynie jako tzw. niesamoistne (na podstawie kryterium możliwości wnoszenia samodzielnie określonego środka, tj. wnoszone jedynie z innym środkiem zaskarżenia, np. zaskarżenie w odwołaniu od decyzji postanowienia, na które stronie nie przysługiwało zażalenie). Zob. W. Taras, Środki prawne - pojęcie i podziały, w: K. Chorąży, W. Taras, A. Wróbel, Postępowanie administracyjne, egzekucyjne i sądowoadministracyjne, Warszawa 2009, s. 99-102. 
Nadzór jako instytucja prawa ustrojowego ${ }^{37}$ spełnia zaś najistotniejszą rolę $\mathrm{w}$ układzie zdecentralizowanym, definiowany nie jako relacja pomiędzy podmiotami należącymi do struktury administracji publicznej, ale jako relacja o charakterze zewnętrznym, przebiegająca między podmiotami niepowiązanymi ze sobą więzami zależności służbowych i osobowych.

$Z$ reguły organ nadzorujący dysponuje środkami nadzoru w stosunku do organów nadzorowanych. Zestaw środków nadzoru określany jest jako prawna lista środków nadzoru, co oznacza, że organ nadzorujący może używać tylko takich środków nadzoru, jakie zostały mu przyznane przez ustawę ${ }^{38}$. Niedopuszczalne jest stosowanie innych środków, nawet gdy organ ten uważa je za skuteczniejsze i mniej dolegliwe dla organu nadzorowanego niż środki prawem przewidziane, chyba że będą to środki o charakterze niewładczym ${ }^{39}$.

\section{Nadzór nad lecznictwem uzdrowiskowym - przedmiotowa sfera nadzoru oraz zakres i kryteria nadzoru}

Ustawodawca uzdrowiskowy w art. 17-32 rozdziału 4 ustawy uzdrowiskowej uregulował "[n]adzór nad lecznictwem uzdrowiskowym”. Przyjęta konstrukcja nawiązuje do poglądu Z. Leońskiego, który podnosi, że „analizując przepisy interesującej nas ustawy w kwestii nadzoru [...], nie można się kierować systematyką ustawy i tym, co ustawodawca nazwał nadzorem, ale istotą środków nadzoru"40. Badany nadzór obejmuje działalność zakładów lecznictwa uzdrowiskowego, które są podmiotami leczniczymi. W celu uporządkowania dalszych wywodów analizie poddano najpierw unormowania wynikające $\mathrm{z}$ ustawy uzdrowiskowej, a następnie regulacje działu VI u.d.l. zatytułowanego „Kontrola i nadzór" unormowane w art. 118-122, będące uzupełnieniem ustawy uzdrowiskowej. Porównanie treści uregulowanych w obu ustawach pozwala stwierdzić, że ustawa uzdrowiskowa jest zdecydowanie

${ }^{37}$ Szerzej zob. J. Dytko, Proceduralnoprawna determinacja nadzoru wojewody nad dziatalnościa prawotwórczą organów jednostek samorządu terytorialnego, Wrocław 2013, s. 39-70, zwł. s. $48-53$.

${ }^{38}$ Zob. np. J. Boć, T. Kuta, Prawo administracyjne. Zagadnienia podstawowe, Warszawa 1984, s. 122-123; E. Olejniczak-Szałowska, Zasady centralizacji i decentralizacji oraz koncentracji i dekoncentracji, w: Prawo administracyjne. Pojęcia, instytucje, zasady w teorii i orzecznictwie, pod red. M. Stahl, Warszawa 2013, s. 180.

${ }^{39}$ E. Ura, Prawo... (2010), s. 73.

${ }^{40}$ Z. Leoński, Samorząd terytorialny..., s. 177. 
bardziej pojemna, gdyż obejmuje siedemnaście artykułów, zaś u.d.l. tylko pięć.

W ramach sfery przedmiotowej nadzór dotyczy lecznictwa uzdrowiskowego, czyli zorganizowanej działalności polegającej na udzielaniu świadczeń opieki zdrowotnej z zakresu leczenia uzdrowiskowego albo rehabilitacji uzdrowiskowej, prowadzonej w uzdrowisku przez zakłady lecznictwa uzdrowiskowego albo poza uzdrowiskiem w szpitalach i sanatoriach znajdujących się w urządzonych podziemnych wyrobiskach górniczych, przy wykorzystaniu warunków naturalnych, takich jak: właściwości naturalnych surowców leczniczych, właściwości lecznicze klimatu, w tym talasoterapia i subterraneoterapia, oraz właściwości lecznicze mikroklimatu - a także towarzyszących zabiegów z zakresu fizjoterapii.

Jeżeli chodzi o zakres nadzoru nad lecznictwem uzdrowiskowym prowadzonym w uzdrowisku w zakładach lecznictwa uzdrowiskowego, to stosownie do art. 18 ustawy uzdrowiskowej „nadzór" oznacza „dokonywanie kontroli i oceny lecznictwa uzdrowiskowego prowadzonego w zakładach lecznictwa uzdrowiskowego". Uwzględniając zatem, że ustawa reguluje i nadzór, i kontrolę nad lecznictwem uzdrowiskowym, wydaje się, iż poprawny tytuł analizowanego rozdziału ustawy uzdrowiskowej powinien brzmieć "kontrola i nadzór nad tego typu formą leczenia”.

Ustawodawca uzdrowiskowy pomimo wprowadzenia definicji nadzoru nie przesądził wprost o jego kryteriach. Wyjaśnienia poszukiwano więc zarówno na gruncie ustawy uzdrowiskowej, jak i u.d.l. Na podstawie dokonanych analiz można stwierdzić, że sfera przedmiotowa nadzoru ${ }^{41}-$ poza sformułowaniem w ustawie uzdrowiskowej, że jest to nadzór nad lecznictwem uzdrowiskowym - stosownie do jej art. $15 \mathrm{z}$ odesłaniem do art. 118 ust. 1 u.d.l. sprowadza nadzór do kryterium zgodności z prawem (legalności z obowiązującymi powszechnie przepisami, z przyjętymi aktami wewnętrznymi, wyrokami, decyzjami administracyjnymi i zawartymi umowami). Jeśli zaś chodzi o kryterium medyczne, to w tym zakresie, jaki został uznany za obowiązujący w ustaleniach zasad sztuki medycznej opartych na podstawach prawnych, a nie tylko na bazie zaleceń wydawanych przez działające $\mathrm{w}$ formie stowarzyszeń różnego rodzaju towarzystwa medyczne. W sytuacji braku powszechnej standaryzacji procesu udzielania świadczeń zdrowotnych ustalenia dokonywane przez towarzystwa medyczne nie są wystarczające, aby uznać je za

${ }^{41}$ Zob. M. Dercz, Komentarz do art. 117-122, w: M. Dercz, T. Rek, Ustawa o działalności leczniczej. Komentarz, Warszawa 2014, s. 464; B. Sygit, D. Wąsik, Kontrola podmiotów leczniczych, Warszawa 2015, s. 27. 
powszechnie obowiązujące lekarzy i pacjentów - innymi słowy, dotyczące standardów organizacyjnych opieki zdrowotnej przyjętych w danych dziedzinach medycyny ${ }^{42}$. Wszystkie rodzaje dokonywanych czynności mogą być przeprowadzane tylko według tych dwóch kryteriów.

Skoro lecznictwo uzdrowiskowe jest prowadzone w zakładach lecznictwa uzdrowiskowego w uzdrowisku będącym wydzielonym obszarem gminy uzdrowiskowej, to bez wątpienia nadzorowi podlegają władze samorządu takiej gminy. Mogą jednak powstać obiekcje, czy przepisy o nadzorze z rozdziału 10 u.s.g. dotyczą także zakładów lecznictwa uzdrowiskowego. Zakłady te rządzą się z reguły specyficznym reżimem prawnym, skierowanym do określonej grupy podmiotów, co przemawiałoby przeciwko przyjęciu tezy, że przepisy o nadzorze odnoszą się również do tych podmiotów. Dlatego należy podzielić stanowisko Z. Leońskiego, zgodnie z którym nadzór nad zakładami może się odbywać według zasad ustalonych zarówno w przepisach prawa ustrojowego ${ }^{43}$, jak i materialnego ${ }^{44}$ prawa administracyjnego dotyczącego różnych typów zakładów ${ }^{45}$.

\section{Właściwe organy oraz środki kontroli i nadzoru nad zakładami lecznictwa uzdrowiskowego według ustawy uzdrowiskowej}

Zgodnie z art. 17 ust. 1 ustawy uzdrowiskowej nadzór nad lecznictwem uzdrowiskowym sprawuje Minister Zdrowia i wojewoda, a w odniesieniu do lecznictwa uzdrowiskowego prowadzonego w zakładach lecznictwa uzdrowiskowego utworzonych przez Ministra Obrony Narodowej $(\mathrm{MON})$ i ministra właściwego do spraw wewnętrznych (MSW) odpowiednio ci ministrowie $\mathrm{w}$ porozumieniu $\mathrm{z}$ Ministrem Zdrowia. Trzeba zasygnalizować, że nadzór nad lecznictwem uzdrowiskowym prowadzonym przez zakłady lecznictwa uzdrowiskowego na obszarze województwa sprawuje wojewoda przy pomocy naczelnego lekarza

${ }^{42}$ Por. K. Wojtczak, Kompetencje i zadania jednostek samorzadu terytorialnego w zakresie bezpieczeństwa zdrowia ludności, „Studia Prawa Publicznego” 2018, nr 3(23), s. 46.

${ }^{43}$ Zob. samorządowe ustawy ustrojowe, do których poza przytoczoną już ustawą o samorządzie gminnym należą: Ustawa z dnia 5 VI 1998 r. o samorządzie powiatowym (tekst jedn. Dz.U. 2020, poz. 920), dalej: „u.s.p.”, oraz Ustawa z dnia 5 VI 1998 r. o samorządzie województwa (tekst jedn. Dz.U. 2020, poz. 1668), dalej: „u.s.w.”.

${ }^{44}$ Chodzi tu zwłaszcza o przepisy rozdziału 4 ustawy uzdrowiskowej i dział VI u.d.l.

${ }^{45}$ Z. Leoński, Zarys prawa administracyjnego, Warszawa 2004, s. 203-204. 
uzdrowiska. Dokonując oceny tej regulacji, można stwierdzić, że nadzorem nad lecznictwem uzdrowiskowym nie rządzi zasada jedności, gdyż jest on sprawowany przez wiele organów. Nadzór nad "całym" lecznictwem uzdrowiskowym, co do zasady, należy do Ministra Zdrowia i wojewody, a w praktyce w drodze wyjątku do MON i MSW, co wynika z niskiej liczby - zaledwie dziesięć - tego typu zakładów określonych według działu II rozdziału 2 u.d.l. jako podmioty lecznicze o szczególnej regulacji. Zestawiając zakres przedmiotowy i podmiotowy nadzoru nad lecznictwem uzdrowiskowym, można zatem już w tym miejscu wywieść, że podstawowe znaczenie ma ustawa uzdrowiskowa.

Zgodnie z art. 20 ust. 1 ustawy uzdrowiskowej w ramach nadzoru Minister Zdrowia jest uprawniony w szczególności do: (1) oceny zgodności lecznictwa uzdrowiskowego z kierunkami leczniczymi; (2) żądania udostępnienia dokumentów związanych z działalnością zakładów lecznictwa uzdrowiskowego oraz zapoznawania się z ich treścią; (3) żądania przekazania wszelkich informacji i wyjaśnień dotyczących działalności zakładów lecznictwa uzdrowiskowego; (4) przeprowadzania kontroli na terenie zakładów lecznictwa uzdrowiskowego i żądania wyjaśnień potrzebnych do oceny ich działalności i jakości świadczeń opieki zdrowotnej oraz funkcjonowania zakładów lecznictwa uzdrowiskowego.

Regulacja ta stanowi podstawę materialnoprawną do władczej ingerencji w zakres merytoryczny funkcjonowania zakładu lecznictwa uzdrowiskowego i określa kompetencje kontrolno-nadzorcze Ministra Zdrowia jako centralnego organu administracji rządowej w zakresie spraw należących do kierowanego przezeń działu administracji zdrowia $^{46}$ (do zakresu jego działania należą m.in. sprawy lecznictwa uzdrowiskowego ${ }^{47}$ ). Minister ten $\mathrm{z}$ natury rzeczy dysponuje środkami oddziaływania na każdą jednostkę organizacyjną ochrony zdrowia, niewyłączoną wyraźnie spod jego kontroli (nadzoru) przepisami ustawy. Co więcej, wyliczenie kompetencji nadzorczych Ministra Zdrowia uregulowanych w art. 20 ust. 1 ustawy uzdrowiskowej nie jest zamkniętym katalogiem jego uprawnień, lecz wskazuje kompetencje o podstawowym znaczeniu ${ }^{48} \mathrm{z}$ punktu widzenia nadzoru nad lecznictwem uzdrowiskowym.

${ }^{46}$ Zob. art. 5 pkt 28 oraz art. 33 ust. 1 pkt 7 Ustawy z dnia 4 IX 1997 r. o działach administracji rządowej (tekst jedn. Dz.U. 2020, poz. 1220).

${ }^{47} \mathrm{~J}$. Lang, Administracja ochrony zdrowia, w: Prawo administracyjne, pod red. M. Wierzbowskiego, s. 500 .

${ }^{48}$ Szerzej zob. P. Kledzik, Nadzór nad lecznictwem..., s. 97. 
Ustawa uzdrowiskowa $\mathrm{w}$ art. $19 \mathrm{w}$ ramach regulacji dotyczących nadzoru nad lecznictwem uzdrowiskowym normuje także zakres zadań Ministra Zdrowia mający charakter otwartego katalogu. Należy do nich w szczególności:

- określanie kierunków działalności uzdrowisk w zakresie lecznictwa uzdrowiskowego;

- ustalanie kierunków leczniczych dla poszczególnych uzdrowisk w oparciu o naturalne surowce o potwierdzonych właściwościach leczniczych i klimat;

- monitorowanie zachowania warunków leczniczych i środowiskowych warunkujących przyznanie i utrzymanie statusu uzdrowiska albo statusu obszaru ochrony uzdrowiskowej;

- określanie wymagań, jakim powinny odpowiadać zakłady lecznictwa uzdrowiskowego i urządzenia lecznictwa uzdrowiskowego;

- potwierdzenie spełnienia warunków koniecznych do nadania danemu obszarowi statusu uzdrowiska albo statusu obszaru ochrony uzdrowiskowej, albo utrzymania tego statusu na podstawie operatu uzdrowiskowego;

- opracowanie wzorcowego statutu uzdrowiska i wzorcowego statutu obszaru ochrony uzdrowiskowej;

- występowanie do Prezesa Rady Ministrów o nadanie danemu obszarowi statusu uzdrowiska albo statusu obszaru ochrony uzdrowiskowej lub pozbawianie danego obszaru takiego statusu;

- ustalanie zasad kierowania i kwalifikowania pacjentów do zakładów lecznictwa uzdrowiskowego;

- rozpatrywanie odwołań od decyzji wojewody.

Natomiast stosownie do analizowanego art. 19 odpowiednio ust. 2 i 3 Ministra Zdrowia upoważniono do określenia w drodze aktów wykonawczych: (1) wymagań, jakim powinny odpowiadać zakłady i urządzenia lecznictwa uzdrowiskowego, kierując się bezpieczeństwem pacjenta i koniecznością zachowania standardów świadczeń opieki zdrowotnej, a także wskazaniami nauki i praktyki (Rozporządzenie Ministra Zdrowia z dnia 2 kwietnia 2012 r. w sprawie określenia wymagań, jakim powinny odpowiadać zakłady i urządzenia lecznictwa uzdrowiskowego $\left.{ }^{49}\right) ;(2)$ sposobu kierowania i kwalifikowania pacjentów do zakładów lecznictwa uzdrowiskowego, w tym przeciwwskazań do leczenia uzdrowiskowego albo rehabilitacji uzdrowiskowej stanowiących

${ }^{49}$ Tekst jedn. Dz.U. 2020, poz. 1838. 
podstawę kwalifikowania pacjenta, kierując się bezpieczeństwem pacjenta, a także wskazaniem nauki i praktyki (Rozporządzenie Ministra Zdrowia z dnia 5 stycznia 2012 r. w sprawie sposobu kierowania i kwalifikowania pacjentów do zakładów lecznictwa uzdrowiskowego ${ }^{50}$ ).

Dokonując analizy i oceny wskazanych regulacji, można stwierdzić, że większość kompetencji Ministra Zdrowia dotyczy statusu prawnego utworzenia uzdrowiska i jego utrzymania ${ }^{51}$, a także działalności zakładów lecznictwa uzdrowiskowego, w ramach których prowadzone jest leczenie uzdrowiskowe. Trudno tu zatem mówić ściśle o kompetencjach nadzorczych.

Według art. 20 ust. 6 ustawy uzdrowiskowej ustawodawca - poprzez sformułowanie odsyłające "odpowiednio" - ustanowił, że przepisy odnoszące się do Ministra Zdrowia mają zastosowanie również do wojewody. Jedyne ustawowe wyjątki, zgodnie z którymi tylko Minister Zdrowia jest uprawniony do określonych czynności w ramach nadzoru nad lecznictwem uzdrowiskowym, dotyczą (1) oceny zgodności lecznictwa uzdrowiskowego z kierunkami leczniczymi, a także (2) rozpatrywania odwołań od decyzji wojewody (art. 19 ust. 1 pkt 1 i 10 ustawy uzdrowiskowej). Tylko ten organ jest władny do ustalania określonych kierunków leczniczych uzdrowisk, co wynika wprost $\mathrm{z}$ art. 19 ust. 1 ustawy uzdrowiskowej. Uzupełnieniem tych regulacji jest art. 30 ust. 1-2 tego aktu, zgodnie z którym jeżeli ze wskazanych wspólnych uprawnień korzysta Minister Zdrowia, zawiadamia o tym właściwego wojewodę, a wojewoda nie podejmuje wówczas odrębnych działań. Przepis ten stosuje się odpowiednio, jeśli z uprawnień kontrolnych korzysta wojewoda ${ }^{52}$. Unormowanie to wprost zatem wskazuje kolejny właściwy organ nadzorczy w zakresie lecznictwa uzdrowiskowego, jakim jest wojewoda ${ }^{53}$. Na tle regulacji

${ }^{50}$ Dz.U. z 2012, poz. 14.

51 Zob. np. P. Łazutka-Gawęda, Organizacja i funkcjonowanie polskich gmin uzdrowiskowych, Narodowy Instytut Samorządu Terytorialnego, "Opinie i Analizy” 2020, nr 50, s. 5.

${ }^{52} \mathrm{Na}$ temat statusu prawnego zob. E. Olejniczak-Szałowska, Ustrój administracji państwowej. Terenowa administracja rządowa, w: Prawo administracyjne. Pojęcia, instytucje..., s. 348; K. Wojtczak, Obsada stanowiska wojewody w przepisach prawnych dawniej i aktualnie obowiazujacych, w: Prawo i Administracja, t. 8, pod red. K. Wojtczak, Piła 2009, s. 7-34.

${ }^{53}$ Ustawa z dnia 23 I 2009 r. o wojewodzie i administracji rządowej w województwie (tekst jedn. Dz.U. 2019, poz. 1464), dalej „u.w.a.r.w.”. Zob. zwł. art. 22 pkt 2 u.w.a.r.w. dotyczący obowiązków wojewody w zakresie wykonywania polityki Rady Ministrów w województwie, który to zapewnia współdziałanie wszystkich organów administracji rządowej i samorządowej działających w województwie i kieruje ich działalnością w zakresie zapobiegania zagrożeniu życia, zdrowia lub mienia oraz zagrożeniom środowiska, bezpieczeństwa państwa i utrzymania porządku publicznego, ochrony praw 
art. 30 ust. 1 i 2 ustawy uzdrowiskowej pojawiają się jednak pewne uwa$\mathrm{gi}^{54}$. Ustawodawca wprowadził tu mianowicie specyficzną właściwość przemienną dwóch organów administracji publicznej, zgodnie z którą obaj są właściwi w sprawach wymienionych w art. 20 ust. 1 pkt 2-4 ustawy uzdrowiskowej i może prowadzić postępowanie, co wyklucza możliwość występowania w sprawie przez drugi organ. Przy czym właściwość miejscowa Ministra Zdrowia obejmuje cały kraj, a wojewody dane województwo. Dalsze analizy odnoszące się do art. 30 badanej ustawy mają oznaczać, że gdy Minister Zdrowia korzysta jako pierwszy z przysługujących mu uprawnień, to następczo wojewodę obowiązuje powstrzymanie się od działań określonych jako odrębne. Mało tego, stosownie do art. 31 ustawy uzdrowiskowej ustawodawca potwierdza, że przepisy art. 20 - a zatem regulujące kwestie uprawnień w ramach nadzoru nad lecznictwem uzdrowiskowym - stosuje się odpowiednio do Ministra Obrony Narodowej i Ministra Spraw Wewnętrznych.

Uwzględniając powyższe uwagi, regulacje dotyczące uprawnień w ramach nadzoru nad lecznictwem uzdrowiskowym poddano wspólnej analizie, dotyczącej wszystkich organów sprawujących nadzór: zarówno Ministra Zdrowia, jak i wojewody, a także MON i MSW. Według art. 20 ust. 2 ustawy uzdrowiskowej Minister Zdrowia (wojewoda, MON, MSW), przedstawiając pisemne żądania, które dotyczą: (1) udostępnienia dokumentów związanych z działalnością zakładów lecznictwa uzdrowiskowego oraz zapoznawania się z ich treścią; (2) przekazania wszelkich informacji i wyjaśnień dotyczących działalności zakładów lecznictwa uzdrowiskowego - wskazuje termin ich wykonania (ust. 2). Jak wynika z art. 20 ust. 3 ustawy uzdrowiskowej, w przypadku stwierdzenia przypadków naruszeń przepisów ustawy Minister Zdrowia powiadamia kierownika zakładu lecznictwa uzdrowiskowego o stwierdzonych nieprawidłowościach oraz: (1) wydaje zalecenia pokontrolne mające na celu usunięcie stwierdzonych nieprawidłowości; (2) wydaje w miarę potrzeby decyzje administracyjne nakazujące usunięcie stwierdzonych nieprawidłowości - wyznaczając termin usunięcia stwierdzonych nieprawidłowości i dostosowania działalności do przepisów ustawy. Decyzja ta jest ostrzejszym środkiem nacisku kontrolującego, nakazującym usunięcie stwierdzonych nieprawidłowości. Przy czym w ślad za

obywatelskich, a także zapobiegania klęskom żywiołowym i innym nadzwyczajnym zagrożeniom oraz zwalczania i usuwania ich skutków, na zasadach określonych w odrębnych ustawach, oraz art. 29 ust. 1-3 u.w.a.r.w. regulujący uprawnienia kontrolne wojewody.

${ }^{54}$ Zob. P. Kledzik, Nadzór nad lecznictwem..., s. 101-102. 
P. Kledzikiem ${ }^{55}$ ze względu na sposób redakcji art. 20 ust. 3 ustawy należy przyjąć, że obowiązek powiadamiania kierownika zakładu lecznictwa uzdrowiskowego dotyczy i nieprawidłowości stwierdzonych w zaleceniu pokontrolnym, i decyzji administracyjnej. Według art. 20 ust. 4 ustawy uzdrowiskowej, w przypadku gdy został złożony wniosek o ponowne rozpatrzenie sprawy, termin do usunięcia nieprawidłowości liczy się od dnia doręczenia zalecenia lub decyzji po rozpatrzeniu wniosku. Natomiast w myśl art. 20 ust. 5 analizowanej ustawy w terminie 14 dni od dnia upływu terminu wyznaczonego do usunięcia nieprawidłowości zakład lecznictwa uzdrowiskowego informuje pise nie Ministra Zdrowia (wojewodę, MON, MSW) o sposobie usunięcia nieprawidłowości. Ustawodawca nie określił jednak wprost charakteru prawnego pisma bądź aktu dotyczącego sposobu ich usunięcia.

Kolejna regulacja dotyczy przeprowadzania kontroli. Zgodnie bowiem $\mathrm{z}$ art. 21 ust. 1-3 ustawy uzdrowiskowej kontrolę w zakładzie lecznictwa uzdrowiskowego przeprowadzają w imieniu Ministra Zdrowia upoważnione osoby, będące pracownikami ministerstwa obsługującego Ministra Zdrowia, albo inne osoby posiadające odpowiednie do przedmiotu kontroli kwalifikacje i doświadczenie zawodowe. Minister Zdrowia w upoważnieniu do przeprowadzenia kontroli określa przedmiot i zakres kontroli oraz wskazuje osobę uprawnioną do przeprowadzenia kontroli. Wskazane przepisy stosuje się odpowiednio do osób przeprowadzających kontrolę w imieniu MON i MSW.

Ustawodawca uzdrowiskowy uwagę poświęca także osobie przeprowadzającej kontrolę w zakładzie lecznictwa uzdrowiskowego. Artykuł 22 ust. 1 ustawy uzdrowiskowej określa zamknięty katalog wyłączeń, gdyż osoba przeprowadzająca kontrolę nie może być jednocześnie: (1) pracownikiem NFZ, świadczeniodawcy, gminy uzdrowiskowej lub zakładu lecznictwa uzdrowiskowego; (2) właścicielem zakładu lecznictwa uzdrowiskowego; (3) świadczeniodawca, który zawarł umowę o udzielanie świadczeń opieki zdrowotnej w rozumieniu u.ś.o.z.; (4) osobą współpracującą z zakładem lecznictwa uzdrowiskowego lub świadczeniodawcą; (5) członkiem organów zakładu ubezpieczeń prowadzącego działalność ubezpieczeniową. Co więcej, zgodnie $z$ art. 20 ust. 2 i 3 analizowanej ustawy taka osoba podlega wyłączeniu od udziału w kontroli z mocy ustawy, jeżeli: (1) pozostaje z zakładem lecznictwa uzdrowiskowego lub gminą uzdrowiskową

${ }^{55}$ Szerzej zob. ibidem, s. 105-106. 
w takim stosunku prawnym lub faktycznym, że wynik kontroli może mieć wpływ na jej prawa lub obowiązki; (2) kontrola dotyczy jej małżonka, krewnych lub powinowatych do drugiego stopnia; (3) kontrola dotyczy osoby związanej z nią z tytułu przysposobienia, opieki lub kurateli. Powyższe powody wyłączenia trwają po ustaniu uzasadniającego je małżeństwa, przysposobienia, opieki lub kurateli. $W$ art. 20 ust. 4 i 5 ustanowiono rozszerzenie powyżej wskazanych wyłączeń, niezależnie bowiem od przyczyn wyłączenia od udziału w kontroli z mocy ustawy Minister Zdrowia wyłącza osobę przeprowadzająca kontrolę na jej żądanie lub na wniosek zakładu lecznictwa uzdrowiskowego lub organu gminy uzdrowiskowej, jeżeli między tą osobą a zakładem lecznictwa uzdrowiskowego zachodzi stosunek osobisty tego rodzaju, że mógłby wywołać wątpliwości co do jej bezstronności. Osoba wyłączona podejmuje wyłącznie czynności niecierpiące zwłoki ze względu na interes społeczny lub ważny interes zakładu lecznictwa uzdrowiskowego. Trzeba podkreślić, że w myśl art. 20 ust. 6 ustawy uzdrowiskowej przepisy dotyczące wyłączeń w zakresie przeprowadzania kontroli stosuje się także do osób przeprowadzających kontrolę w imieniu MON i MSW.

Stosownie do art. 23 ustawy uzdrowiskowej Minister Zdrowia może zwracać się do właściwych służb i inspekcji z wnioskiem o przeprowadzenie kontroli w zakresie przestrzegania przepisów o ochronie środowiska, lecz według kontroli prowadzonej przez Najwyższą Izbę Kontroli Minister Zdrowia nigdy nie korzystał z tego uprawnienia ${ }^{56}$.

Specyfika uzdrowiska sprawia, że w myśl art. 17 ust. 2 ustawy uzdrowiskowej wojewoda sprawuje nadzór nad lecznictwem uzdrowiskowym prowadzonym przez zakłady lecznictwa uzdrowiskowego na obszarze województwa przy pomocy naczelnego lekarza uzdrowiska, a według jej art. 24 ust. 3 naczelny lekarz uzdrowiska, za pośrednictwem wojewody, co 12 miesięcy składa informację o swojej działalności Ministrowi Zdrowia.

Naczelny lekarz uzdrowiska sprawuje nadzór nad jakością ${ }^{57}$ świadczeń opieki zdrowotnej udzielanych przez zakłady lecznictwa uzdrowiskowego (art. 24 ust. 2 ustawy uzdrowiskowej). Przy czym art. 24a ust. 1

${ }^{56}$ Kontrola NIK, Spetnianie wymogów określonych dla uzdrowisk (P/16/091), Nr ewid. 179/2016/P/16/091/LSZ, LSZ.430.003.2016, s. 16 i 44.

${ }^{57}$ Por. A. Ponikowska, A. Styś, B. Iwankiewicz-Rok, Typowanie głównych parametrów jakości w lecznictwie uzdrowiskowym, Torun 2001, s. 12-13. Zob. też art. 17 ust. 2 oraz art. 24 ust. 1-3 ustawy uzdrowiskowej. 
tego aktu stanowi w zasadzie analogiczne rozwiązania, jak te przyjęte przez ustawodawcę w zakresie uprawnień nadzorczych wojewody. Należałoby jednak te kwestie uporządkować. O ile nadzór sprawowany przez wojewodę odnosi się do całego lecznictwa uzdrowiskowego, to naczelny lekarz uzdrowiska uprawniony jest wyłącznie do nadzoru nad jakością świadczeń opieki zdrowotnej udzielanych przez zakłady lecznictwa uzdrowiskowego, będące jednym z elementów działalności lecznictwa uzdrowiskowego.

Ustawodawca ustanowił zamknięty katalog wyłączeń odnoszących się do przeprowadzania kontroli na terenie zakładów lecznictwa uzdrowiskowego i żądania wyjaśnień potrzebnych do oceny ich działalności i jakości udzielanych przez nie świadczeń zdrowotnych oraz funkcjonowania tych zakładów. W myśl art. 24a ust. 2 ustawy uzdrowiskowej naczelny lekarz uzdrowiska nie może przeprowadzać kontroli, jeżeli jest: (1) właścicielem zakładu lecznictwa uzdrowiskowego; (2) świadczeniodawca, który zawarł umowę o udzielanie świadczeń opieki zdrowotnej w rozumieniu przepisów u.ś.o.z.; (3) osobą współpracującą z zakładem lecznictwa uzdrowiskowego lub świadczeniodawcą. W przypadkach tych kontrolę przeprowadzają w imieniu Ministra Zdrowia upoważnione osoby będące pracownikami ministerstwa albo inne posiadające odpowiednie do przedmiotu kontroli kwalifikacje i doświadczenie zawodowe.

Ustawa uzdrowiskowa w art. 27 ust. 1-5 nakłada obowiązek prowadzenia przez naczelnego lekarza uzdrowiska ewidencji zakładów lecznictwa uzdrowiskowego i urządzeń lecznictwa uzdrowiskowego występujących na obszarze uzdrowiska. Obecnie jest to wykaz zakładów lecznictwa uzdrowiskowego sklasyfikowany na podstawie złożonych operatów przez 45 uzdrowisk ${ }^{58}$. Zmiana ma na celu ujednolicenie prowadzonej przez naczelnych lekarzy uzdrowisk dokumentacji, a także usystematyzowanie informacji dotyczących liczby i rodzajów zakładów oraz typów urządzeń lecznictwa uzdrowiskowego występujących na obszarze uzdrowiska. Przy czym rada gminy nie jest władna, na podstawie przyznanego w art. 42 ust. 4 u.d.l. upoważnienia, do regulowania w statucie materii dotyczącej zasad kontroli podmiotów leczniczych, gdyż sprawy te zostały już unormowane w samej u.d.1. ${ }^{59}$

${ }^{58}$ Wykaz uzdrowisk wraz z kierunkami leczniczymi, https://www.gov.pl/web/zdrowie/ wykaz-uzdrowisk-wraz-z-kierunkami-leczniczymi (dostęp: 10 IX 2021).

${ }^{59}$ Rozstrzygnięcie Nadzorcze Wojewody Dolnośląskiego z dnia 2 VIII 2012 r., NK-N17.4131.219.2012.RJ1. 
Stosownie do art. 27 ust. 1 i 3 ustawy uzdrowiskowej naczelny lekarz uzdrowiska prowadzi dokumentację związaną z nadzorem nad lecznictwem uzdrowiskowym oraz ewidencję zakładów lecznictwa uzdrowiskowego znajdujących się na obszarze uzdrowiska. Kierownik zakładu lecznictwa uzdrowiskowego zgłasza zakład lecznictwa uzdrowiskowego do ewidencji po uzyskaniu wpisu tego zakładu do rejestru podmiotów wykonujących działalność lecznicza, o którym mowa w u.d.l., przy czym zgodnie z jej art. 106 ust. 1 pkt 1 organem prowadzącym rejestr w odniesieniu do podmiotów leczniczych będących zakładami lecznictwa uzdrowiskowego jest wojewoda właściwy dla siedziby podmiotu leczniczego. $Z$ tej regulacji wynika, że wojewodowie prowadzą rejestry wszystkich rodzajów podmiotów leczniczych, co jest konsekwencją pierwotnego zamiaru twórców u.d.l., tj. całkowitego pozostawienia rejestracji podmiotów wykonujących działalność leczniczą w gestii wojewody.

Właściwość tego ostatniego ustala się w przypadku zakładów lecznictwa uzdrowiskowego na podstawie siedziby danego podmiotu leczniczego. Właściwym wojewodą jest ten, w którego województwie mieści się (będzie się mieścić) siedziba podmiotu leczniczego. Konkretną miejscowość powinien określać formalnie w osobnym dokumencie jego założyciel, gdyż regulamin organizacyjny tego nie reguluje. $W$ razie wątpliwości co do miejsca udzielania świadczeń zdrowotnych można stosować art. 41 Kodeksu cywilnego ${ }^{60}$, choć wyłącznie do podmiotów leczniczych wyposażonych w przymiot osobowości prawnej, który przewiduje - o ile ustawa lub oparty na niej statut nie stanowią inaczej że siedzibą osoby prawnej jest miejscowość, w której ma siedzibę jej organ zarządzający. Przepisy u.d.l. nie rozstrzygają kwestii podmiotów, których wszystkie jednostki organizacyjne zlokalizowane są na terenie innego (innych) województwa niż to, w którym znajduje się siedziba założyciela podmiotu leczniczego. Taki podmiot podlega wpisowi do rejestru w województwie, w którym mieści się jego siedziba, a nie miejsce udzielania świadczeń zdrowotnych. Na podstawie art. 27 ust. 5 ustawy uzdrowiskowej kierownik zakładu lecznictwa uzdrowiskowego jest obowiązany niezwłocznie zgłosić naczelnemu lekarzowi uzdrowiska zmiany danych objętych ewidencją.

Na marginesie warto zauważyć, że ustawodawca w analizowanym art. 27 ustawy uzdrowiskowej trafnie posługuje się dwoma pojęciami: "ewidencja” i „rejestr". Co więcej, przegląd literatury także pozwala na ich

${ }^{60}$ Ustawa z dnia 23 IV 1964 r. - Kodeks cywilny (tekst jedn. Dz.U. 2020, poz. 1740). 
rozróżnienie ${ }^{61}$. Jeśli podmiot prowadzący jedynie przyjmował określone dokumenty czy dane, bez prawa do merytorycznej kontroli i modyfikacji wniosków, stwierdzano, że jest to ewidencja. Rejestrem określano zbiór, w którym podmiot prowadzący kontrolował składane dokumenty, mogąc żądać wprowadzenia zmian lub odmówić ich ujawnienia (dokonania wpisu). Uwzględniając skutki prawne wpisu, stwierdzano, że wpis do ewidencji ma charakter wyłącznie informacyjny, a wpis do rejestru pociąga za sobą skutki w sferze prawa materialnego. Ewidencja miała pełnić głównie funkcje ewidencyjną i informacyjna, rejestry zaś funkcje ochronną, prawotwórczą i kontrolną. Obecnie przydatny jest podział na rejestry notyfikacyjne (oparte na zbieraniu dokumentów), rejestry oparte na wpisie i analiza funkcjonalna instytucji. Jak wynika $z$ orzecznictwa ${ }^{62}$, ewidencja ma charakter porządkowy, rejestr natomiast pełni funkcje ochronne w stosunku do wpisanych do niego podmiotów i do osób trzecich. Wiąże się z tym jawność rejestrów i zapewnienie możliwości dostępu do zawartych w nich danych; cechy te nie są charakterystyczne dla ewidencji. Wpis do rejestru wywiera zwykle istotne skutki prawne (np. nabycie osobowości prawnej przez organizację wpisaną do rejestru), podczas gdy wpis do ewidencji skutków takich nie ma. Prowadzenie rejestru wymaga bardziej sformalizowanego postępowania niż prowadzenie ewidencji.

Minister Zdrowia, kierując się koniecznością zapewnienia prawidłowego nadzoru nad zakładami lecznictwa uzdrowiskowego, określił w drodze Rozporządzenia z dnia 29 lipca 2011 r. w sprawie naczelnego lekarza uzdrowiska ${ }^{63}$ szczegółowy zakres obowiązków i uprawnień naczelnego lekarza uzdrowiska, dotyczących sprawowania nadzoru nad lecznictwem uzdrowiskowym, który obejmuje nadzór nad jakością świadczeń opieki zdrowotnej udzielanych w zakładach lecznictwa uzdrowiskowego, przez kontrolę i ocenę: zgodności rodzaju i zakresu udzielanych świadczeń opieki zdrowotnej z rodzajem i zakresem świadczeń opieki zdrowotnej określonymi w statucie; zgodności udzielanych świadczeń zdrowotnych ze wskazaniami aktualnej wiedzy medycznej; kwalifikacji osób udzielających świadczeń zdrowotnych; ponadto przez

${ }^{61}$ Zob. G. Szpor, C. Martysz, K. Wojsyk, Ustawa o informatyzacji, Warszawa 2015, s. 72-73; Rejestry publiczne. Jawność i interoperacyjność, pod red. A. Gryszczyńskiej, Warszawa 2016, s. 9.

${ }^{62}$ Zob. postanowienie SN z 23 III 1995 r., sygn. III CZP 5/95, OSNC 1995, nr 7-8, poz. 106.

${ }^{63}$ Dz.U. Nr 161, poz. 976. 
rozpatrywanie skarg i wniosków pacjentów korzystających ze świadczeń opieki zdrowotnej udzielanych w zakładach lecznictwa uzdrowiskowego; kontrolę wyposażenia zakładów lecznictwa uzdrowiskowego w aparaturę lub sprzęt medyczny służące do udzielania świadczeń zdrowotnych, odpowiednio do rodzaju i zakresu świadczeń opieki zdrowotnej określonych w statucie, oraz sprawdzanie dokumentacji dotyczącej terminów konserwacji, działań serwisowych, przeglądów, regulacji, kalibracji, wzorcowań, sprawdzeń i kontroli bezpieczeństwa aparatury lub sprzętu medycznego; kontrolę warunków zakwaterowania i wyżywienia pacjentów w zakładach lecznictwa uzdrowiskowego (§ 2).

Rozporządzenie określa także szczegółowe zadania naczelnego lekarza uzdrowiska oraz zakres współpracy pomiędzy nim i podmiotami tworzącymi. Zakres zadań naczelnego lekarza uzdrowiska obejmuje: występowanie do konsultantów krajowych lub wojewódzkich o opinie w sprawach związanych z lecznictwem uzdrowiskowym; monitorowanie wykorzystania naturalnych surowców leczniczych przez zakłady lecznictwa uzdrowiskowego; inicjowanie porozumień pomiędzy podmiotami będącymi właścicielami urządzeń lecznictwa uzdrowiskowego w sprawie właściwego wykorzystania tych urządzeń; współdziałanie z komisją uzdrowiskową ( 3 3). Naczelny lekarz uzdrowiska współpracuje $\mathrm{z}$ podmiotami tworzacymi $\mathrm{w}$ zakresie: przestrzegania praw pacjenta w zakładach lecznictwa uzdrowiskowego; rozwoju lecznictwa uzdrowiskowego na obszarze swojego działania; utrzymania urządzeń lecznictwa uzdrowiskowego; organizacji szkoleń dla osób udzielających świadczeń zdrowotnych; inwestycji, zwłaszcza w zakresie infrastruktury uzdrowiskowej; działań promocyjnych lecznictwa uzdrowiskowego; ochrony środowiska na obszarach ochrony uzdrowiskowej; zdrowia publicznego i promocji zdrowia (§ 4).

\section{Właściwe organy oraz środki kontroli i nadzoru nad zakładami lecznictwa uzdrowiskowego według ustawy o działalności leczniczej}

Zagadnienie kontroli i nadzoru nad zakładami lecznictwa uzdrowiskowego, które przecież są podmiotami leczniczymi, trudno analizować w oderwaniu od działu IV u.d.l. Ustawa ta określa bowiem kompetencje kontrolne Ministra Zdrowia i działających w jego imieniu wojewodów, którzy samoistnie mają tylko kompetencję dopuszczająca 
przeprowadzanie czynności kontrolnych w zakresie rejestracji podmiotów leczniczych. Czynności kontrolne związane z przestrzeganiem prawa przez te podmioty mogą być zlecane tylko przez Ministra Zdrowia. Co więcej, wskazany dział normuje także nadzór nad podmiotem leczniczym. Trzeba zatem zaznaczyć, że „[z]godnie z komentowanym działem prawo kontroli podmiotów leczniczych przysługuje Ministrowi Zdrowia i podmiotom działającym na jego zlecenie. Nadzór natomiast dotyczy wyłącznie podmiotów leczniczych niebędących przedsiębiorcami i uprawnienie do jego prowadzenia mają podmioty tworzące danego podmiotu leczniczego" 64 .

Jak już wiadomo, zakres kontroli reguluje art. 118 u.d.l. Zgodnie z jego ust. 1 Minister Zdrowia ma prawo przeprowadzania kontroli podmiotów leczniczych a więc zakładów lecznictwa uzdrowiskowego pod względem: zgodności z prawem i medycznym. W ramach kontroli zgodności z prawem w myśl art. 118 ust. 2 u.d.l. Minister Zdrowia w szczególności jest uprawniony do: (1) wizytacji pomieszczeń; (2) obserwowania czynności związanych z udzielaniem świadczeń zdrowotnych w sposób nienaruszający praw pacjenta; a także oceny: (3) uzyskanej dokumentacji medycznej; (4) informacji i dokumentacji innej niż dokumentacja medyczna; (5) realizacji zadań określonych $\mathrm{w}$ regulaminie organizacyjnym w zakresie dostępności i jakości udzielanych świadczeń zdrowotnych; (6) realizacji zadań określonych w regulaminie organizacyjnym; (7) gospodarowania mieniem oraz środkami publicznymi. Jak podkreśla się w doktrynie ${ }^{65}$, prawo Ministra do kontroli nie obejmuje osób wykonujących zawód w ramach praktyk zawodowych, ponieważ nie stanowi to prowadzenia podmiotu leczniczego (art. 5 ust. 3 u.d.l.). Prawo kontroli praktyk jest ograniczone do działań kontrolnych samorządów zawodowych. Uwagę zwraca ust. 4 analizowanego art. 118 u.d.l., w myśl którego obserwowanie czynności w zakresie: udzielania świadczeń zdrowotnych w sposób nienaruszający praw pacjenta; oceny uzyskanej dokumentacji medycznej, a także oceny realizacji zadań określonych w regulaminie organizacyjnym w zakresie

${ }^{64}$ J. Nowak-Kubiak, Ustawa o działalności leczniczej. Komentarz, Warszawa 2012, s. 405.

${ }^{65}$ Ibidem, s. 406. Zob. też M. Urbaniak, Monitorowanie funkcjonowania systemu ochrony zdrowia. Kontrola nad działalnościa podmiotów leczniczych, w: Organizacja systemu ochrony zdrowia, seria System Prawa Medycznego, t. 3, pod red. D. Bach-Goleckiej, R. Stankiewicza, Warszawa 2020, s. 912-917. 
dostępności i jakości udzielanych świadczeń zdrowotnych, może być realizowane wyłącznie przez osobę wykonującą zawód medyczny ${ }^{66}$.

Artykuł 119 u.d.l. reguluje kwestie możliwości zlecenia kontroli innym podmiotom, do wykonywania której umocowanie posiada Minister Zdrowia. Zgodnie z ust. 1 tego przepisu Minister Zdrowia może zlecić przeprowadzenie kontroli: wojewodom, konsultantom krajowym ${ }^{67}$, jednostkom organizacyjnym podległym lub nadzorowanym przez tego ministra. Poza tym stosownie do art. 119 ust. 2 u.d.l. Minister Zdrowia może zlecić, na podstawie umowy, odpłatne przeprowadzenie jednorazowej kontroli dotyczącej obserwowania czynności związanych z udzielaniem świadczeń zdrowotnych w sposób nienaruszający praw pacjenta: organom samorządów zawodów medycznych, medycznym towarzystwom naukowym, uczelniom medycznym, instytutom badawczym, specjalistom z poszczególnych dziedzin medycyny. Zlecenie może być zleceniem stałym lub czasowym ${ }^{68}$.

Ustawodawca, kierując się kryterium fachowości, w art. 119 ust. 1 u.d.l. wskazał listę podmiotów zobligowanych ustawowo do podjęcia zleconych przez Ministra Zdrowia czynności kontrolnych, wśród których jest wojewoda. Jak zaś wynika z ust. 3 zd. 2 tego artykułu, wojewoda może zlecić przeprowadzenie zleconej mu kontroli podmiotom wymienionym w art. 111 ust. 5 u.d.l., czyli konsultantom wojewódzkim i jednostkom organizacyjnym podległym lub nadzorowanym przez wojewodę. Zlecenie powinno być dokonane w sposób formalny i poprzedzone uzyskaniem zgody od zleceniobiorcy. Najlepszą formą byłaby pisemna umowa, której elementami byłyby upoważnienie do określonego zakresu kontroli i imienne wskazanie, kogo ta kontrola dotyczy. Możliwa jest przy tym sytuacja, w której kontroli chce dokonać zarówno wojewoda w toku postępowania rejestrowego, jak i Minister Zdrowia w toku zwykłego postępowania kontrolnego.

Wskazane powyżej podmioty ustawowo zobligowane do podjęcia czynności kontrolnych mają zatem otwarty katalog uprawnień

${ }^{66}$ Osoba wykonująca zawód medyczny to osoba uprawniona na podstawie odrębnych przepisów do udzielania świadczeń zdrowotnych oraz osoba legitymująca się nabyciem fachowych kwalifikacji do udzielania świadczeń zdrowotnych w określonym zakresie lub w określonej dziedzinie medycyny (art. 2 pkt 2 u.d.l.).

${ }^{67}$ Ustawa z dnia 6 XI 2008 r. o konsultantach w ochronie zdrowia (tekst jedn. Dz.U. 2019, poz. 886).

${ }^{68}$ J. Nowak-Kubiak, Ustawa..., s. 411. Kontrola z art. 119 ust. 1 u.d.l. nie będzie zlecana w drodze umowy, lecz w drodze zlecenia organu administracji państwowej podległym organowi (ministrowi) jednostkom. 
uregulowanych w art. 118 u.d.l. Organy kontrolujące upoważnione są w toku wizytacji m.in. do ustalenia, czy pomieszczenia, urządzenia podmiotu leczniczego i stosowane wyroby medyczne odpowiadaja określonym wymaganiom. Wizytacja ma związek z czynnościami rejestrowymi. Stwierdzenie w jej toku nieprawidłowości powoduje, że organ kontrolujący ma prawo wydać zalecenia pokontrolne. Brak możliwości wydania decyzji administracyjnej nakazującej wizytowanemu podmiotowi usunięcie uchybień utrudnia skuteczne kwestionowanie przez podmiot zasadności wydanych zaleceń.

Kilka z tych czynności kontrolnych wymaga głębszej refleksji. Organy kontrolujące upoważnione są w toku wizytacji m.in. do ustalenia, czy pomieszczenia i urządzenia podmiotu leczniczego odpowiadaja określonym w rozporządzeniu ${ }^{69}$ wymaganiom, czy nabyte i stosowane wyroby medyczne odpowiadają wymaganiom Ustawy z dnia 20 maja 2010 r. o wyrobach medycznych ${ }^{70}$. Przeprowadzenie wizytacji ma także związek z czynnościami rejestrowymi. Stwierdzenie nieprawidłowości w jej toku powoduje, że organ kontrolujący ma prawo wydać zalecenia pokontrolne. Aktualnie brakuje możliwości wydania stosownej decyzji administracyjnej nakazującej wizytowanemu podmiotowi usunięcie uchybień, przez co utrudnione jest skuteczne kwestionowanie przez podmiot zasadności sporządzonych zaleceń.

Przedmiotem oceny uzyskanej dokumentacji medycznej są dokonywane wpisy oraz dodatkowa dokumentacja uwzględniająca aspekty techniczne gromadzenia dokumentacji, zapisy merytoryczne, upoważnienia i zgody na wykonywanie świadczeń zdrowotnych. Natomiast w zakresie oceny informacji i dokumentacji innej niż dokumentacja medyczna nie określono jednoznacznie, w jakiej formie ma być podana informacja, możliwa jest zatem również forma ustna. Informacje i dokumenty dotyczą całej działalności kontrolowanego podmiotu leczniczego, a nie tylko tej związanej z procesem wykonywania świadczeń zdrowotnych.

Dla pacjenta zakładu lecznictwa uzdrowiskowego duże znaczenie ma także ocena realizacji zadań określonych w regulaminie organizacyjnym w zakresie dostępności i jakości ${ }^{71}$ udzielanych świadczeń

${ }^{69}$ Por. art. 22 ust. 3 u.d.l. oraz Rozporządzenie Ministra Zdrowia z dnia 26 III 2019 r. w sprawie szczegółowych wymagań, jakim powinny odpowiadać pomieszczenia i urządzenia podmiotu wykonującego działalność leczniczą (Dz.U. poz. 595).

${ }^{70}$ Tekst jedn. Dz.U. 2021, poz. 1565.

${ }^{71}$ Zob. Kontrola NIK, Wykorzystywanie naturalnych surowców leczniczych w lecznictwie uzdrowiskowym, Nr ewid. 170/2018/P/18/098/LSZ, LSZ.430.003.2018, s. 12, w której 
zdrowotnych. Minister Zdrowia, prowadząc kontrolę pod względem zgodności z prawem oraz medycznym, ma możliwość uzyskiwania wszelkich informacji i dokumentów od pracowników kontrolowanego podmiotu, przy czym czynności te mogą być przeprowadzane wyłącznie przez osoby wykonujące zawód medyczny.

W ramach czynności kontrolnych organ ma prawo do oceny gospodarki mieniem oraz środkami publicznymi. Nie wiadomo jednak, czy chodzi tu o środki publiczne czy w ogóle o środki. W u.d.l. w odniesieniu do gospodarowania mieniem nie wskazano, jaka gospodarka mieniem jest prawidłowa. Ze względu na brak ustawowych kryteriów ocennych np. zakup urządzenia medycznego może nie być prawidłowym gospodarowaniem, ale wystarczającym, gdyż pozwala na poprawę stanu zdrowia pacjentów. Wydaje się ponadto, że określono tu szeroki zakres ingerencji podmiotów rządowych. Chociaż według art. 171 ust. 1 Konstytucji RP działalność samorządu terytorialnego podlega nadzorowi z punktu widzenia legalności, w porównaniu z przeprowadzaniem kontroli pod względem oceny gospodarności podmiotów samorządowych, art. 118 ust. 1 u.d.l. budzi obawy o jego całkowitą legalnośćc ${ }^{72}$.

Kontrola podmiotów leczniczych pod względem medycznym dotyczy sposobu i zakresu merytorycznego czynności kontrolnych, wykonywanych przez kontrolerów wykonujących zawód medyczny, i innych świadczeń pomocniczych realizowanych jako wsparcie świadczeń zdrowotnych. Czynności kontrolne mogą być podejmowane tylko przez kontrolujących posiadających wiedzę i wiadomości specjalistyczne z zakresu medycyny i prawa medycznego. W przypadku zakładów lecznictwa uzdrowiskowego dotyczy to tylko profesjonalnej kadry medycznej ${ }^{73}$.

Zgodnie $\mathrm{z}$ art. 120 u.d.1. Minister Zdrowia informuje podmiot tworzący o wynikach przeprowadzonej kontroli. Przepis ten nie przesądza, do podjęcia jakiego działania podmiot tworzący jest zobowiązany. Słuszny jest pogląd M. Potocznego ${ }^{74}$, zgodnie z którym "[p]rzepis ten ma bardzo

mówi się o braku standardów dotyczących wykonywania zabiegów bodźcowych, w tym norm zużycia naturalnych surowców leczniczych, co prowadzi do niemożliwości oceny sposobu wykonywania tych zabiegów i zastosowania właściwej ilości naturalnych surowców leczniczych.

${ }^{72}$ Zob. M. Dercz, Komentarz do art. 117-122, s. 472 i n.

${ }^{73}$ Por. D. Kotarski, Funkcjonowanie kontroli zewnętrznej i zarządczej w zakładach lecznictwa uzdrowiskowego, Zeszyty Naukowe Uniwersytetu Szczecińskiego „Finanse, Rynki Finansowe, Ubezpieczenia" 2011, nr 42, s. 136.

${ }^{74}$ M. Potoczny, Komentarz do art. 21, w: Ustawa o działalnośćleczniczej. Komentarz, pod red. F. Grzegorczyka, Warszawa 2013, s. 437. 
ogólny charakter. Jak się wydaje, chodzi wyłącznie o zapewnienie podmiotowi zobowiązanemu do sprawowania nadzoru nad danym podmiotem leczniczym [...] informacji o ustaleniach kontroli, dotyczących nadzorowanej przez niego działalności".

W ramach art. 121 u.d.l. uregulowany jest nadzór nad podmiotem leczniczym niebędącym przedsiębiorca, który sprawuje podmiot tworzący. Stosownie do ust. 2 analizowanej regulacji nadzór dotyczy zgodności działań tego typu podmiotu leczniczego z przepisami prawa, statutem i regulaminem organizacyjnym oraz pod względem celowości, gospodarności i rzetelności. W rozumieniu art. 121 ust. 3 u.d.l. nadzór to m.in. "dokonywanie kontroli i oceny działalności tego podmiotu”. Pojęcie nadzoru oznacza prawo władczego wkraczania w działalność jednostki nadzorowanej, a organ nadzorczy jest współodpowiedzialny za prawidłowe funkcjonowanie nadzorowanego podmiotu leczniczego. Podmiot uprawniony do sprawowania nadzoru (organ mający uprawnienia nadzorczo-kontrolne) nad samorządowymi organami założycielskimi $^{75}$ określają ustawy ustrojowe ${ }^{76}$. Pozostaje otwarte pytanie, który z organów jest władny do zarządzenia i przeprowadzenia kontroli podmiotu leczniczego na podstawie art. 121 u.d.1. ${ }^{77}$ Orzecznictwo sądów administracyjnych nie jest w tej materii jednolite. W części wyroków ${ }^{78}$ przyjmuje się, że organem kompetencyjnie właściwym jest organ wykonawczy, w innych zaś ${ }^{79}$, że jest to organ stanowiący (działający głównie poprzez właściwe komisje rewizyjne ${ }^{80}$ ).

${ }^{75}$ Jak podnosi P. Szetela (Rola samorzadu terytorialnego w polskim systemie ochrony zdrowia: organizator, podmiot tworzacy oraz płatnik, "Zdrowie Publiczne i Zarządzanie" 2015, nr 13(1), s. 56-57), "[o]d 1990 roku w Polsce odbywa się postępujący proces decentralizacji funkcji zdrowotnych państwa. Na JST stopniowo przekazywano wiele zadań z zakresu ochrony zdrowia, m.in. przejęcie funkcji organizatora ochrony zdrowia na poziomie lokalnym i regionalnym (pełnienie roli organów założycielskich publicznych zakładów opieki zdrowotnej)".

${ }^{76}$ Jeśli chodzi o organy inne niż samorządowe, czynności nadzorcze realizują osoby reprezentujące te podmioty i przeprowadzanie ich odbywa się na podstawie imiennego upoważnienia wydanego przez podmiot tworzący.

${ }^{77}$ K. Wojtczak, Kompetencje i zadania..., s. 47.

${ }^{78}$ Zob. np. wyrok Wojewódzkiego Sądu Administracyjnego (WSA) w Warszawie z 9 III 2015 r., sygn. VII SA/Wa 2996/14, Legalis nr 1244953.

${ }^{79}$ Zob. np. wyrok Naczelnego Sądu Administracyjnego (NSA) z 30 III 2017 r., sygn. II OSK 1906/15, Legalis nr 1605064.

${ }^{80}$ Kontrola komisji rewizyjnej w Sopocie nt. „Kontrola działalności za rok 2016 SP ZOZ Uzdrowisko Sopot". Zob. uchwała Nr XXXVII 503/2018 z dnia 19 lutego 2018 r. w sprawie przyjęcia sprawozdania z działalności Komisji Rewizyjnej Rady Miasta Sopotu 
Przedmiot i kryteria kontroli mogą być różne, a ich precyzyjne określenie należy do organu nadzorującego. Może on przeprowadzić kontrolę w sposób całościowy lub poprzestać na pewnym zakresie aktywności podmiotu. Kontrola i ocena obejmują w szczególności: realizację zadań określonych w regulaminie organizacyjnym i statucie, dostępność i jakość udzielanych świadczeń zdrowotnych, prawidłowość gospodarowania mieniem i środkami publicznymi, gospodarkę finansową ${ }^{81}$, której podstawę stanowi plan finansowy ustalany przez kierownika samodzielnego publicznego zakładu opieki zdrowotnej (s.p.z.o.z.). Katalog spraw mogących być przedmiotem nadzoru z art. 121 ust. 4 u.d.l. nie jest zatem zamknięty w wyniku użycia sformułowania "w szczególności”. Oznacza to, że wskazane w przepisie kwestie muszą być skontrolowane, możliwe jest jednak nadzorowanie podmiotu leczniczego także w innych aspektach.

Zgodnie $z$ art. 121 ust. 5 u.d.l. podmiot tworzący $w$ razie stwierdzenia niezgodnych z prawem działań kierownika wstrzymuje ich wykonanie oraz zobowiązuje kierownika do ich zmiany lub cofnięcia. $Z$ analizy zd. 1 tego przepisu wynika, że ustawodawca nie przewidział procedury odwoławczej w tym zakresie. Mało tego, w przypadku niedokonania zmiany lub cofnięcia tych działań w wyznaczonym terminie podmiot tworzący może rozwiązać z kierownikiem stosunek pracy albo umowę cywilnoprawną. Zgodnie zaś z ust. 8 art. 121 u.d.l. Minister, centralny organ administracji rządowej lub wojewoda, będący podmiotem tworzącym, wykonuje kontrolę podmiotu leczniczego niebędącego przedsiębiorcą na zasadach i w trybie określonych w przepisach o kontroli w administracji rządowej ${ }^{82}$.

Praktyczne aspekty postępowań kontrolnych reguluje art. 122 u.d.l. Kontrolę przeprowadza się na podstawie upoważnienia udzielonego odpowiednio przez Ministra Zdrowia albo podmiot tworzący, zarówno w podmiotach leczniczych będących przedsiębiorcami, jak i niebędących nimi, czyli s.p.z.o.z. W prowadzonym postępowaniu kontrolnym ${ }^{83}$

za okres 29 sierpnia do 31 grudnia 2017 roku i pkt 5 załącznika dotyczący wspominanej kontroli, https://bip.sopot.pl/m,198,uchwaly-rady-miasta-2018.html (dostęp: 10 IX 2021).

${ }^{81}$ Problemy płynności finansowej nadzorowanego podmiotu powodujące zadłużenia oraz problem bierności podmiotów tworzących w zakresie nadzoru, którą w sytuacji złej gospodarki finansowej s.p.z.o.z. jako sektora finansów publicznych można traktować jako naruszającą dyscyplinę finansów publicznych, omawia m.in. M. Dercz, Komentarz do art. 117-122, s. 472.

${ }^{82}$ Ustawa z dnia 15 VII 2011 r. o kontroli w administracji rządowej (tekst jedn. Dz.U. 2020, poz. 224), dalej: „u.k.a.r.”.

${ }^{83}$ Szczegółowy tryb przeprowadzania kontroli został doprecyzowany w drodze Rozporządzenia Ministra Zdrowia z dnia 20 XII 2012 r. w sprawie sposobu i trybu przeprowadzania kontroli podmiotów leczniczych (tekst jedn. Dz.U. 2015, poz. 1331). 
można wyróżnić trzy etapy ${ }^{84}$ : (1) upoważnienie do przeprowadzenia kontroli, (2) przebieg postępowania kontrolnego oraz (3) sporządzenie wystąpienia pokontrolnego i zaleceń pokontrolnych nakazujących usunięcie stwierdzonych nieprawidłowości. Wykonanie licznych czynności kontrolnych przyjęto krytycznie ${ }^{85}$, gdyż niosą one spory wysiłek logistyczny i finansowy.

Na podstawie art. 106 ust. 1 u.d.l. w zw. z art. 108 ust. 2 pkt 4 u.d.l. w zw. z art. 109 ust. 1 i 3 u.d.l. w przypadku niezastosowania się do zaleceń pokontrolnych wojewoda jako organ prowadzaccy rejestr podmiotów leczniczych wydaje decyzję o wykreśleniu zakładu leczniczego z tego rejestru. $W$ odniesieniu do nadzoru i kontroli dokonywanych przez podmioty tworzące zaliczane do administracji rządoweje ${ }^{86}$ powinna być uwzględniana treść normatywna normująca te zagadnienia w odniesieniu do administracji rządowej uregulowana w u.k.a.r.

Oceniając u.d.l. w kontekście nadzoru i kontroli nad podmiotami leczniczymi, do których należą zakłady lecznictwa uzdrowiskowego, jawi się problem braku regulacji niezbędnych do utrzymania przez władze publiczne stanu bezpieczeństwa zdrowotnego, w wyniku czego nie jest możliwe wprowadzenie systemu wczesnego ostrzegania o zagrożeniach związanych z płynnością dostępu do świadczeń opieki zdrowotnej ${ }^{87}$.

\section{Odrębne tryby kontroli prowadzonej na obszarze o statusie uzdrowiska}

Lecznictwo uzdrowiskowe jako integralna część systemu ochrony zdrowia jest prowadzone w zakładach lecznictwa uzdrowiskowego w uzdrowiskach. Podmioty sprawujące nadzór nad lecznictwem

${ }^{84}$ Etapy te są uregulowane odpowiednio w art. 119 ust. 2 u.d.l, art. 122 ust. 3 u.d.l. i art. 122 ust. $4-5$ u.d.l.

${ }^{85}$ Tak M. Dercz, Komentarz do art. 117-122, s. 462-476.

${ }^{86}$ Zob. „Informacja o wynikach kontroli na temat: Funkcjonowanie SP ZOZ MSWiA w zakresie wybranych zadań zrealizowanej w Samodzielnym Publicznym Zakładzie Opieki Zdrowotnej Sanatorium Uzdrowiskowym MSWiA w Kołobrzegu". Tryb kontroli: kontrola została przeprowadzona przez Departament Kontroli i Nadzoru Ministerstwa Spraw Wewnętrznych i Administracji w trybie zwykłym, zgodnie z Planem kontroli Ministerstwa Spraw Wewnętrznych i Administracji na rok 2019. Termin kontroli: od 5 IV 2019 r. do 28 VI 2019 r. i od 19 VII 2019 r. do 23 VIII 2019 r., https://www.gov.pl/ web/mswia/wystapienia-pokontrolne-2019 (dostęp: 10 IX 2021).

${ }^{87}$ Por. M. Dercz, Komentarz do art. 100-113, w: M. Dercz, T. Rek, Ustawa o działalności... (2014), s. 437. 
uzdrowiskowym obowiązano m.in. do dokonania systematycznej kontroli i oceny działalności zakładów lecznictwa uzdrowiskowego. Przedmiotem rozważań w bieżącym punkcie będą odrębne tryby prowadzenia kontroli w uzdrowisku, tj. kontrole: wewnętrzna, zarządcza i doraźna.

Kontrola wewnętrzna to kontrola sprawowana przez podmioty należące do systemu jednostek organizacyjnych administracji państwowej ${ }^{88}$. Ustawą uzdrowiskową ustanowiono odrębny w stosunku do pozostałych podmiotów leczniczych obowiązek prowadzenia kontroli wewnętrznej we wszystkich zakładach lecznictwa uzdrowiskowego. Ten odrębny reżim kontroli wiąże się ze stworzeniem przez ustawodawcę specyficznego zestawu norm ${ }^{89}$. Według art. 32 omawianego aktu Minister Zdrowia, po zasięgnięciu opinii MON i MSW, określa odrębny szczegółowy sposób i tryb przeprowadzania kontroli, uwzględniając właściwą realizację celów kontroli oraz zapewnienie jej szybkości i skuteczności.

W tym zakresie obowiązuje Rozporządzenie Ministra Zdrowia z dnia 10 marca 2006 r. w sprawie szczegółowego sposobu i trybu przeprowadzania kontroli w zakładach lecznictwa uzdrowiskowego ${ }^{90}$. Organy wskazane w art. 17 ustawy uzdrowiskowej, czyli Minister Zdrowia, MON, MSW, wojewoda i naczelny lekarz uzdrowiska, w myśl tego aktu wykonawczego są podmiotami kontrolującymi. Przeprowadzenie kontroli koncentruje się głównie na ustaleniu stanu faktycznego w zakresie realizacji lecznictwa uzdrowiskowego przez zakład lecznictwa uzdrowiskowego i dotyczy: (1) realizacji statutowych zadań zakładów, (2) prawidłowego udokumentowania leczenia, (3) dokonania oceny działalności zakładu, (4) oceny jakości udzielanych świadczeń opieki zdrowotnej, (5) wskazania osób odpowiedzialnych za stwierdzone nieprawidłowości. Kontrola wewnętrzna może wykazać, czy w takim zakładzie doszło do naruszenia dyscypliny finansów publicznych, popełnienia przestępstwa lub wykroczenia skarbowego. Ustalenia stanu faktycznego na podstawie zebranych dowodów dokonuje osoba

${ }^{88}$ Zob. J. Lang, Kontrola administracji, w: Prawo administracyjne, pod red. M. Wierzbowskiego, s. 335 .

${ }^{89}$ Szerzej zob. A. Szpor, Kontrola zarzadcza a mediacja w administracji publicznej, „Kontrola Państwowa" 2011, nr 5(340), s. 8-28, zwł. s. 22.

${ }^{90}$ Dz.U. Nr 47, poz. 346 ze zm. 
przeprowadzająca kontrolę. Efektem końcowym procedur kontrolnych jest wystapienie pokontrolne ${ }^{91}$.

Niektóre zakłady lecznictwa uzdrowiskowego - utworzone przez właściwego ministra, wojewodę lub j.s.t. - mają ustawowy obowiązek prowadzenia kontroli zarządczej. Kontrola zarządcza to ogół działań podejmowanych dla zapewnienia realizacji celów i zadań w sposób zgodny z prawem, efektywny, oszczędny i terminowy. Szczegółowe cele kontroli zarządczej wychodzą znacznie poza zakres ustaleń przewidzianych dla kontroli wewnętrznej w analizowanych zakładach ${ }^{92}$. W podmiotach tych w myśl art. 69 Ustawy z dnia 27 sierpnia 2009 r. o finansach publicznych ${ }^{93}$ należy zapewnić funkcjonowanie adekwatnej, skutecznej i efektywnej kontroli zarządczej. Kierownicy zakładów lecznictwa uzdrowiskowego są odpowiedzialni za zapewnienie kontroli zarządczej, odpowiednie monitorowanie i ocenę jej stosowania. Celem standardów kontroli zarządczej ${ }^{94}$ jest promowanie wdrażania w sektorze finansów publicznych spójnego i jednolitego modelu owej kontroli, zgodnego z międzynarodowymi standardami w tym zakresie. Jednocześnie zakłada się możliwość realizacji specyficznych i indywidualnych zadań w jednostkach prowadzących różną działalność.

W przypadku sanatoriów oraz innych zakładów lecznictwa uzdrowiskowego można zaobserwować potrzebę wartościowania celów i zadań wynikających z przyjętych planów finansowo-rzeczowych oraz dokumentów o znaczeniu strategicznym. Z kolei do istotnych zadań i mierników działalności leczniczej można zaliczyć: realizację planowanej liczby przyjęć pacjentów (skierowanych na leczenie przez NFZ i korzystających z pełnej odpłatności), utrzymanie kosztów na poziomie nieprzekraczającym przyjętego planu finansowego, realizację zadań inwestycyjnych (modernizacyjnych). Ważne są zadania związane z prawidłowo prowadzoną rachunkowością i sprawozdawczością finansową.

${ }^{91}$ Zawiera ono ocenę działalności kontrolowanego zakładu, wynikającą z ustaleń zawartych w sporządzonym protokole kontroli, opis przyczyn powstania nieprawidłowości, ich zakres i skutki, listę osób za nie odpowiedzialnych, a także uwagi, wnioski i zalecenia w sprawie ich usunięcia.

${ }_{92}$ Szerzej zob. D. Kotarski, Funkcjonowanie kontroli zewnętrznej i zarzadczej..., s. 131138. Tego typu kontrola definiowana jest na potrzeby funkcjonowania jednostek sektora finansów publicznych.

${ }_{93}^{3}$ Tekst jedn. Dz.U. 2021, poz. 305, dalej "u.f.p.”.

${ }^{94}$ D. Kotarski, Określanie celów i zadań sanatorium uzdrowiskowego na potrzeby kontroli zarzadczej, Zeszyty Naukowe Uniwersytetu Szczecińskiego „Finanse, Rynki Finansowe, Ubezpieczenia" 2012, nr 53, s. 319. 
Audyt wewnętrzny prowadzi się w jednostkach sektora finansów publicznych (publiczne zakłady lecznictwa uzdrowiskowego) na podstawie u.p.f. Ustawa ta określa audyt jako działalność niezależną i obiektywną, której celem jest wspieranie ministra kierującego działem lub kierownika jednostki w realizacji celów i zadań przez systematyczną ocenę kontroli zarządczej i czynności doradcze. W uzdrowisku zadania przypisane kierownikowi jednostki organizacyjnej związanej z audytem wykonuje wójt (burmistrz, prezydent miasta).

System kontroli zarządczej stosowanej w sanatorium uzdrowiskowym ${ }^{95}$ powinien podlegać bieżącemu monitorowaniu i ocenie. Standard kontroli zarządczej nr $22^{96}$ zakłada wymóg uzyskania zapewnienia o stanie kontroli zarządczej przez kierownika jednostki. Źródłem powinny być wyniki: monitorowania, samooceny oraz przeprowadzonych audytów i kontroli. Zgodnie z ustawą uzdrowiskową i u.d.l. w przypadku działalności sanatoryjnej źródłem informacji o kontroli zarządczej i realizacji zadań może być: monitoring realizacji celów i zadań, samoocena kontroli zarządczej i jej standardy dla sektora finansów publicznych, system zarządzania ryzykiem, audyt wewnętrzny, kontrola wewnętrzna.

W uzdrowisku występuje jeszcze inny rodzaj kontroli. Zgodnie z art. 2 pkt 8 u.f.p. wojewoda jako dysponent środków budżetowych rozporządza częściami budżetu państwa. W myśl art. 175 ust. 1 pkt 2 u.f.p. dysponenci sprawują nadzór i kontrolę m.in. w odniesieniu do wykorzystania dotacji udzielonych z budżetu państwa. Na tej podstawie urząd wojewódzki przeprowadza w urzędzie gminy uzdrowiskowej kontrolę doraźnąe realizacji zadań związanych z zachowaniem funkcji leczniczych przez gminy uzdrowiskowe ${ }^{98}$. Umowę zawiera wojewoda

${ }^{95}$ Oświadczenie cząstkowe o stanie kontroli zarządczej za 2020 - SPZOZ Sanatorium Uzdrowiskowe MSWiA w Kołobrzegu, http://bip.msw.kolobrzeg.pl/userfiles/ file/02/cz\%C4\%85stkowe \%20o\%C5\%9Bwiadczenie \%20o\%20stanie $\% 20$ kontroli $\% 20$ zarzadczej\%20za\%20rok\%202020.pdf (dostęp: 10 IX 2021).

${ }^{96}$ Komunikat nr 23 Ministra Finansów z dnia 16 IX 2009 r. (Dz.Urz. Ministra Finansów 2009, nr 15, poz. 84).

${ }^{97} \mathrm{Z}$ punktu widzenia pozycji organu dokonującego kontroli i podmiotu kontrolowanego w zakładzie lecznictwa uzdrowiskowego oprócz kontroli wewnętrznej można wyróżnić kontrolę zewnętrzną prowadzoną przez jednostki specjalnie do tego wyspecjalizowane. Zob. K. Lewandowska, T. Lewandowski, Wprowadzenie, w: iidem, Ustawa o kontroli w administracji rzadowej. Komentarz, LEX/el. 2013, https://sip.lex.pl/ komentarze-i-publikacje/komentarze/ustawa-o-kontroli-w-administracji-rzadowej-komentarz-587388086 (dostęp: 10 IX 2021).

${ }_{98}$ Zob. np. „Prawidłowość ustalenia wysokości należnej dotacji przyznanej gminie uzdrowiskowej na realizację zadań własnych związanych z zachowaniem funkcji 
z gminą uzdrowiskową reprezentowaną przez wójta (burmistrza, prezydenta miasta) w sprawie udzielenia $\mathrm{z}$ budżetu państwa dotacji na realizację zadań własnych. Na podstawie dowodów księgowych ${ }^{99}$ ustala się, czy przyznaną dotację wykorzystano na realizację zadania. Muszą być one zgodne z uregulowaniami wewnętrznymi jednostki kontrolowanej (polityka rachunkowości, instrukcja obiegu i kontroli dokumentów finansowo-księgowych) i posiadać podziałki klasyfikacji budżetowej. Dowody te są oceniane pod względem zgodności z danymi ujętymi w ewidencji księgowej. Badana jest terminowość regulowania zobowiązań i wpływ na rachunek wskazany na fakturach. W wyniku przeprowadzonej kontroli stwierdza się, czy przyznaną gminie dotację wykorzystano w pełnej wysokości i zgodnie z przeznaczeniem. Działalność gminy w zakresie objętym kontrolą ocenia się pozytywnie lub negatywnie. Omówiony rodzaj kontroli to kontrola międzyresortowa, gdyż organ administracyjny powołany do kontrolowania organów nawet innych resortów niż te, do którego on sam należy, jest organem kontroli zewnętrznej w stosunku do organów kontrolowanych, lecz zarazem jest organem kontroli wewnętrznej, jeśli administrację państwową traktować jako całośćc ${ }^{100}$.

\section{Podsumowanie}

Podstawowa funkcja nadzoru nad samorządem terytorialnym to zaspokajanie potrzeb publicznych. Gmina uzdrowiskowa, realizując ten cel, podlega nadzorowi ze strony państwa. Nadzór nad lecznictwem uzdrowiskowym sprawuje administracja rządowa, dokonując kontroli i oceny lecznictwa uzdrowiskowego prowadzonego w zakładach lecznictwa uzdrowiskowego pod względem zgodności z prawem i medycznym. Organami nadzoru są Minister Zdrowia i wojewoda, Minister Obrony Narodowej i Minister Spraw Wewnętrznych. Specyfika uzdrowiska sprawia natomiast, że wojewoda, będący zasadniczym ogniwem terenowej administracji rządowej, sprawuje nadzór nad lecznictwem

leczniczych uzdrowiska w 2017 r.", termin kontroli 4-5 XII 2019 r.; por. wystąpienie pokontrolne Wojewody Zachodniopomorskiego nr K-1.431.2.2.2019.6.AK, pismo z dnia 9 III 2020 r., http://kolobrzeg2000.home.pl/bip/kontrole/zewnetrzne/2019/21.pdf (dostęp: 10 IX 2021).

${ }_{99}$ Zob. art. 21 ust. 1 Ustawy z dnia 29 IX 1994 r. o rachunkowości (tekst jedn. Dz.U. 2021, poz. 217).

${ }^{100}$ Zob. J. Starościak, Prawo administracyjne, Warszawa 1977, s. 352. 
uzdrowiskowym prowadzonym przez zakłady lecznictwa uzdrowiskowego na obszarze województwa przy pomocy naczelnego lekarza uzdrowiska.

Ustawa uzdrowiskowa stanowi podstawę materialnoprawną władczej ingerencji w zakres merytoryczny działania zakładu lecznictwa uzdrowiskowego, określa kompetencje kontrolno-nadzorcze i wiodące znaczenie Ministra Zdrowia jako centralnego organu administracji rządowej kierującego działem zdrowie w zakresie spraw lecznictwa uzdrowiskowego. Dysponuje on środkami oddziaływania na każdą jednostkę organizacyjną ochrony zdrowia, niewyłączoną wyraźnie spod jego kontroli (nadzoru). Zakresy uprawnień kontrolno-nadzorczych Ministra Zdrowia i wojewody są zasadniczo tożsame, z jednym wyjątkiem: tylko Minister Zdrowia jest uprawniony do określonych czynności w ramach nadzoru nad lecznictwem uzdrowiskowym, tj. do oceny zgodności lecznictwa uzdrowiskowego z kierunkami leczniczymi. Tylko ten organ jest upoważniony do ustalania tych kierunków, co wynika ze specyfiki i indywidualnych uwarunkowań poszczególnych uzdrowisk.

Zakłady lecznictwa uzdrowiskowego jako podmioty lecznicze objęte są także kontrolą i nadzorem na podstawie ustawy o działalności leczniczej, stanowiącej uzupełnienie ustawy uzdrowiskowej. Ustawodawca, kreując nadzór nad lecznictwem uzdrowiskowym, nie dokonuje podziału na podmioty lecznicze publiczne i niepubliczne. Dlatego duże znaczenie dla funkcjonowania zakładów lecznictwa uzdrowiskowego ma nadzór nad podmiotem leczniczym niebędącym przedsiębiorcą regulowany w u.d.l., gdyż sprawuje go podmiot tworzący. Jest to istotne, gdy to gmina uzdrowiskowa tworzy tego typu zakład.

Odrębny tryb prowadzonej kontroli w uzdrowisku dotyczy kontroli wewnętrznej i zarządczej, których celem jest zapewnienie prawidłowej realizacji zadań w zakładach lecznictwa uzdrowiskowego i racjonalne gospodarowanie posiadanymi zasobami. Ze względu na stosowanie celu standardów kontroli zarządczej, kontrola ta ma szerszy zakres niż wewnętrzna, gdyż znacznie wychodzi poza działania mające na celu ustalenie stanu faktycznego realizacji zadań statutowych. Procedury i sposoby zapewnienia adekwatnej, skutecznej i efektywnej kontroli zarządczej poprzez monitorowanie i ocenę jej funkcjonowania ewoluują w praktyce zarządczej zakładów lecznictwa uzdrowiskowego. Dlatego ten rodzaj kontroli stanowi substytut innych narzędzi kontroli zarządczej, zwłaszcza audytu wewnętrznego. Poza kontrolą wewnętrzną 
i zewnętrzną w uzdrowisku występuje kontrola doraźna (będąca kontrolą międzyresortową), prowadzona przez wojewodę, której przedmiotem jest realizacja zadań związanych z zachowaniem funkcji leczniczych uzdrowiska przez gminy uzdrowiskowe.

Wielość regulacji prawnych dotyczących uprawnień w zakresie kontroli i nadzoru nad lecznictwem uzdrowiskowym i zakładami lecznictwa uzdrowiskowego będącymi podmiotami leczniczymi budzi jednak wątpliwości interpretacyjne. Mankamentem jest i to, że przepisy są rozproszone $\mathrm{w}$ wielu aktach prawnych, co powoduje, że siatka pojęciowa w nich przyjęta jest niejednolita. Wyniki analizy unormowań w obecnym kształcie są sygnałem do podjęcia kroków legislacyjnych mających na celu uporządkowanie tego fragmentu prawa administracyjnego.

\section{SUPERVISION OVER SPA TREATMENT WITH PARTICULAR EMPHASIS ON CONTROL AND SUPERVISION ACTIVITIES OVER SPA TREATMENT FACILITIES}

\section{Su m mary}

Spa treatment, which constitutes an integral part of health care, is an organized activity consisting in providing health care services in the field of spa treatment or spa rehabilitation carried out in a spa by spa treatment facilities. In order to ensure the proper and efficient operation of this form of treatment in specially adapted facilities that are medical entities, this treatment is subject to professional supervision. Supervision over health resort treatment entails the control and evaluation of health resort treatment carried out in health resort treatment establishments. This issue is regulated primarily in the Act of 28 July 2005 on spa treatment, health resorts and health resort protection areas and in health resort communes, as well as in the Act of 15 April 2011 on medical activity.

The study contains an analysis and evaluation of the legal regulations concerning the supervision of spa treatment. It discusses the basic terms related to spa issues and presents some concepts of control and supervision in terms of the doctrine. Spa supervision is characterized by specific regulations and the degree of complexity. This applies to individual issues that allow the reconstruction of the essence of supervision. These are the supervisory authorities, subject of supervision, the supervised entities, criteria and scope of supervision exercised and legal means of supervision. The authorities supervising the health resort treatment include the Minister of Health, the Voivode, the Minister of National Defense and the Minister of the Interior. In this article, in the analysis of the scope of his competences and control and supervisory powers great attention is paid to the Minister of Health as the central body of government administration in the field of matters belonging to the department of health administration managed by him. Due to the specific 
nature of supervision of this treatment carried out in the voivodeship, the legal position of the chief physician of the health resort, with whose help the voivode exercises this supervision, was analyzed. Since spa treatment is carried out in spa facilities in a health resort, the study contains the problem of separate control procedures carried out in this area, within which special attention is paid to internal, management and ad hoc control.

Keywords: control and supervision - spa treatment - spa treatment facility - health resort commune and health resort

\section{LITERATURA}

Boć J., Kuta T., Prawo administracyjne. Zagadnienia podstawowe, Warszawa 1984.

Chmielnicki P., Akty nadzoru nad działalnością samorządu terytorialnego w Polsce, Warszawa 2006.

Dawidowicz W., Zagadnienia ustroju administracji państwowej w Polsce, Warszawa 1970.

Dercz M., Komentarz do art. 1, w: M. Dercz, T. Rek, Ustawa o działalności leczniczej. Komentarz, Warszawa 2019.

Dercz M., Komentarz do art. 100-113, w: M. Dercz, T. Rek, Ustawa o działalności leczniczej. Komentarz, Warszawa 2014.

Dercz M., Komentarz do art. 117-122, w: M. Dercz, T. Rek, Ustawa o działalności leczniczej. Komentarz, Warszawa 2014.

Dolnicki B., Nadzór nad samorządem terytorialnym, Katowice 1993.

Dolnicki B., Samorząd terytorialny, Kraków 2001.

Dulińska M., Komentarz do działu VI - art. 118-122, w: Ustawa o działalności leczniczej. Komentarz, pod red. F. Grzegorczyka, Warszawa 2013.

Dytko J., Proceduralnoprawna determinacja nadzoru wojewody nad działalnościa prawotwórcza organów jednostek samorządu terytorialnego, Wrocław 2013.

Jagielski J., Kontrola administracji publicznej, Warszawa 2007.

Janku Z., Kontrolowanie samorzadu terytorialnego, w: Księga jubileuszowa prof. dr. hab. S. Jędrzejowskiego, pod red. W. Szwajdlera, H. Nowickiego, Toruń 2009.

Jaroszyński M., Zimmermann M., Brzeziński W., Polskie prawo administracyjne. Część ogólna, Warszawa 1956.

Jędrzejewski S., Nowicki H., Kontrola administracji publicznej, Toruń 1995.

Kledzik P., Nadzór nad lecznictwem uzdrowiskowym, w: Szczególny status gminy uzdrowiskowej - z perspektywy 10 lat obowiązywania ustawy o lecznictwie uzdrowiskowym, uzdrowiskach i obszarach ochrony uzdrowiskowej oraz o gminach uzdrowiskowych, pod red. E. Koniuszewskiej, Szczecin 2016.

Kmieciak Z., Odwołania w postępowaniu administracyjnym, Warszawa 2011.

Knosala E., Zarys nauki administracji, Kraków 2005.

Kontrola NIK, Spetnianie wymogów określonych dla uzdrowisk (P/16/091), Nr ewid. 179/2016/P/16/091/LSZ, LSZ.430.003.2016.

Kontrola NIK, Wykorzystywanie naturalnych surowców leczniczych w lecznictwie uzdrowiskowym, Nr ewid. 170/2018/P/18/098/LSZ, LSZ.430.003.2018. 
Korczak J., Gmina uzdrowiskowa w prawodawstwie polskim, "Opolskie Studia Administracyjno-Prawne" 2018, t. 16, nr 1(1).

Kotarski D., Funkcjonowanie kontroli zewnętrznej i zarzadczej w zakładach lecznictwa uzdrowiskowego, Zeszyty Naukowe Uniwersytetu Szczecińskiego „Finanse, Rynki Finansowe, Ubezpieczenia" 2011, nr 42.

Kotarski D., Określanie celów i zadań sanatorium uzdrowiskowego na potrzeby kontroli zarządczej, Zeszyty Naukowe Uniwersytetu Szczecińskiego „Finanse, Rynki Finansowe, Ubezpieczenia" 2012, nr 53.

Lang J., Kontrola administracji, w: Prawo administracyjne, pod red. M. Wierzbowskiego, Warszawa 2017.

Lang J., Administracja ochrony zdrowia, w: Prawo administracyjne, pod red. M. Wierzbowskiego, Warszawa 2017.

Leoński Z., Nadzór nad działalnościa gminy, Warszawa 1992.

Leoński Z., Samorząd terytorialny w RP, Warszawa 2002.

Leoński Z., Zarys prawa administracyjnego, Warszawa 2004.

Leoński Z., Zarys prawa administracyjnego. Działalność administracji, Warszawa 2001.

Lewandowska K., Lewandowski T., Wprowadzenie, w: iidem, Ustawa o kontroli w administracji rzadowej. Komentarz, LEX/el. 2013, https://sip.lex.pl/komentarze-i-publikacje/komentarze/ustawa-o-kontroli-w-administracji-rzadowej-komentarz-587388086 (dostęp: 10 IX 2021).

Łazutka-Gawęda P., Organizacja i funkcjonowanie polskich gmin uzdrowiskowych, Narodowy Instytut Samorządu Terytorialnego, „Opinie i Analizy” 2020, nr 50.

Miemiec M., Prewencja i weryfikacja w ramach nadzoru $i$ kierownictwa w ujeciu tradycyjnym, w: Nadzór administracyjny. Od prewencji do weryfikacji, pod red. C. Kocińskiego, Wrocław 2006.

Nowak-Kubiak J., Ustawa o działalności leczniczej. Komentarz, Warszawa 2012.

Ochendowski E., Prawo administracyjne. Czesść ogólna, Torun 1999.

Ochendowski E., Prawo administracyjne. Część ogólna, Torun 2013.

Olejniczak-Szałowska E., Ustrój administracji państwowej. Terenowa administracja rzadowa, w: Prawo administracyjne. Pojęcia, instytucje, zasady w teorii i orzecznictwie, pod red. M. Stahl, Warszawa 2013.

Olejniczak-Szałowska E., Zasady centralizacji i decentralizacji oraz koncentracji i dekoncentracji, w: Prawo administracyjne. Pojecia, instytucje, zasady w teorii i orzecznictwie, pod red. M. Stahl, Warszawa 2013.

Ponikowska A., Styś A., Iwankiewicz-Rok B., Typowanie głównych parametrów jakości w lecznictwie uzdrowiskowym, Torun 2001.

Potoczny M., Komentarz do art. 21, w: Ustawa o działalność leczniczej. Komentarz, pod red. F. Grzegorczyka, Warszawa 2013.

Prawo administracyjne, pod red. J. Bocia, Wrocław 2005.

Rejestry publiczne. Jawność i interoperacyjność, pod red. A. Gryszczyńskiej, Warszawa 2016.

Ryś K., Konstytucyjne prawo do ochrony zdrowia i prawo do szczególnej opieki zdrowotnej, "Zeszyty Naukowe Prawa Konstytucyjnego" 2017, nr 10.

Sikora K., Szczególny status gmin uzdrowiskowych w Polsce, "Studia Iuridica Lublinensia" 2014, nr 23.

Sługocki J., Prawo administracyjne, Kraków 2003. 
Starościak J., Elementy nauki administracji, Warszawa 1964.

Starościak J., Prawo administracyjne, Warszawa 1977.

Starościak J., Zarys nauki administracji, Warszawa 1971.

Sygit B., Wąsik D., Kontrola podmiotów leczniczych, Warszawa 2015.

Szetela P., Rola samorzadu terytorialnego w polskim systemie ochrony zdrowia: organizator, podmiot tworzacy oraz płatnik, "Zdrowie Publiczne i Zarządzanie” 2015, nr 13(1).

Szewczyk M., Nadzór w materialnym prawie administracyjnym, Poznań 1996.

Szpor A., Kontrola zarzadcza a mediacja w administracji publicznej, „Kontrola Państwowa" 2011, nr 5(340).

Szpor G., Martysz C., Wojsyk K., Ustawa o informatyzacji, Warszawa 2015.

Szreniawski J., Wstęp do nauki administracji, Lublin 2004.

Taras W., Środki prawne - pojęcie i podziały, w: K. Chorąży, W. Taras, A. Wróbel, Postępowanie administracyjne, egzekucyjne i sądowoadministracyjne, Warszawa 2009.

Ura E., Prawo administracyjne, Warszawa 2010.

Ura E., Prawo administracyjne, Warszawa 2012.

Urbaniak M., Monitorowanie funkcjonowania systemu ochrony zdrowia. Kontrola nad działalnością podmiotów leczniczych, w: Organizacja systemu ochrony zdrowia, seria System Prawa Medycznego, t. 3, pod red. D. Bach-Goleckiej, R. Stankiewicza, Warszawa 2020.

Wierzbowski M., Wiktorowska A., Podstawowe pojęcia teoretyczne w nauce prawa administracyjnego, w: Prawo administracyjne, pod red. M. Wierzbowskiego, Warszawa 2017.

Wiktorowska A., Prawne determinanty samodzielności gminy. Zagadnienia administracyjnoprawne, Warszawa 2002.

Wiktorowska A., Samorzad terytorialny, w: Prawo administracyjne, pod red. M. Wierzbowskiego, Warszawa 2017.

Winczorek P., Komentarz do Konstytucji polskiej z dnia 2 kwietnia 1997 r., Warszawa 2000.

Wojtczak K., Kompetencje i zadania jednostek samorzadu terytorialnego w zakresie bezpieczeństwa zdrowia ludności, „Studia Prawa Publicznego” 2018, Nr 3 (23).

Wojtczak K., Obsada stanowiska wojewody w przepisach prawnych dawniej i aktualnie obowiazujących, w: Prawo i Administracja, t. 8, pod red. K. Wojtczak, Piła 2009.

Wykaz uzdrowisk wraz z kierunkami leczniczymi, https://www.gov.pl/web/zdrowie/ wykaz-uzdrowisk-wraz-z-kierunkami-leczniczymi (dostęp: 10 IX 2021).

Zimmermann J., Prawo administracyjne, Kraków 2006.

Zimmermann J., Prawo administracyjne, Warszawa 2012.

Zimmermann J., Prawo administracyjne, Warszawa 2014.

Zimna T., Nadzór i kontrola w zakładach lecznictwa uzdrowiskowego, ABC nr 72409, LEX \el., https://sip.lex.pl/komentarze-i-publikacje/komentarze-praktyczne/ nadzor-i-kontrola-w-zakladach-lecznictwa-469834457 (dostęp: 10 IX 2021). 